\title{
تطبيقات تحليلية لنموذج الاستجابة في رفع كفاية الطلاقة القرائية
}

\author{
جملات السعيد عبر النعم فرحات
}

$$
\begin{aligned}
& \text { الملخص: }
\end{aligned}
$$

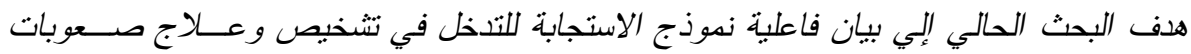

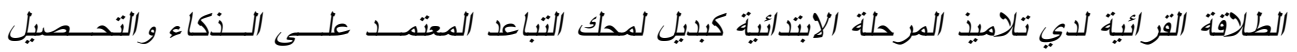

$$
\begin{aligned}
& \text { وقد شملت عبنة البحث قبل تحديد التلاميذ ذوي صعوبات الطلاقة القرائية (1 ـ0) تلميذاً وتلميذة } \\
& \text { الدراسي. }
\end{aligned}
$$

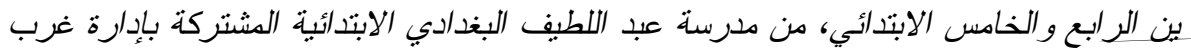

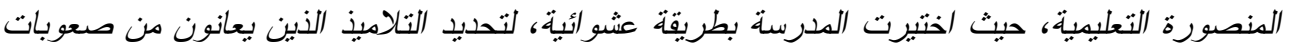

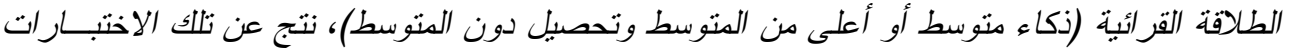

$$
\begin{aligned}
& \text { عينة مكونة من (^) ثمانية تلاميذ انطبق عليهم خصائص صعوبات الطلاقة القرائية، وتم تطبيـق أدوات التئن }
\end{aligned}
$$

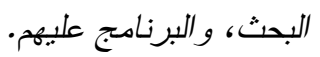

$$
\begin{aligned}
& \text { وقد أظهرت نتائج البحث عن التالئي: }
\end{aligned}
$$

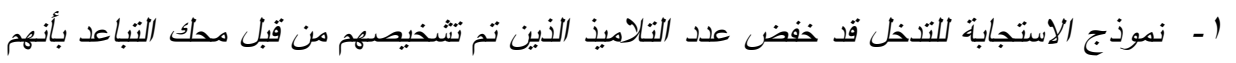

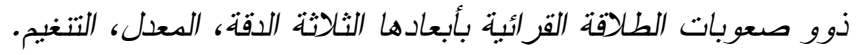

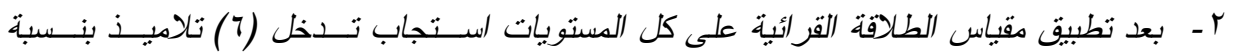

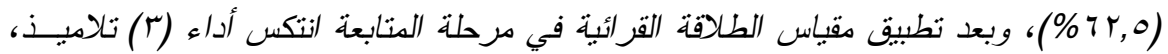

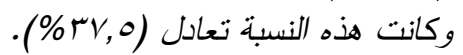

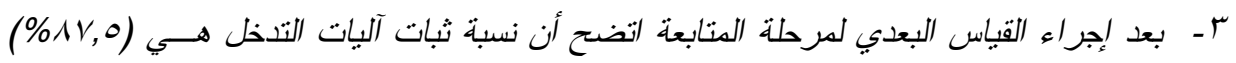

$$
\begin{aligned}
& \text { وذللك بعد أن انتكس تلميذ واحد من التلاميذ المستجبيين للتندل. }
\end{aligned}
$$

\section{Abstract}

The research aimed at demonstrate the effectiveness of the response to intervention model in the diagnosis and treatment of reading fluency LD of Primary students as an alternative model to the discrepancy norm, that is based upon the IQ and the academic achievement of the student.

The research applied on a sample consisting of students(501) in the fourth and fifth primary years of the school of Abd Al-Latif Al Baghdadi common primary, west of Mansoura management, I chose students from the school randomly to identify pupils who suffer from difficulties in reading fluency( an average, above-average or below average intelligence). The result of those tests is (8) students have the characteristic of learning difficulties of reading fluency.

\section{The results of the research reveal the following:}

1- The response of intervention model has redused the number of pupils who are diagnosed by a spacing model test. They have difficulties in reading fluency in its three skills(reading accuracy, rate and prosodic reading). 
2- After preforming the reading fluency criterion on all levels (6) students responded to intervention by $(62.5 \%)$, and after preforming the reading fluency criterion in the follow-up stage the performance of three students reduced, that is, the precentage of those who reduced after the intervention is $(37.5 \%)$.

3- After preforming the Deimensional criterion in the follow-up stage it is turned out that the proportion of intervention mechanisms is $(87.5 \%)$. Thats is after only one student of the pupils don't respond to intervention.

مقدمة

$$
\begin{aligned}
& \text { أكثر من هــــه المكونـــات، و التـــي تمثـــل }
\end{aligned}
$$

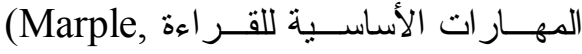

$$
\begin{aligned}
& .2012,54) \\
& \text { يشير (Kavale,2002) بأن استخدام } \\
& \text { التباعد بين الذكاء و التحصيل الدر اسي كمعيار } \\
& \text { في تحديد ذوي صعوبات التعلم، يجعل مــن } \\
& \text { الصعب تحديد التلاميذ ذوي صعوبات التعلم } \\
& \text { في الصفوف الأولى بسبب عــدم اســتقرار }
\end{aligned}
$$

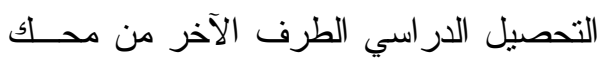

$$
\begin{aligned}
& \text { التباعد مما يؤدي إلى ظاهرة انتظار الفثل. } \\
& \text { لذا كان من الضروري دراسة واحــــ }
\end{aligned}
$$

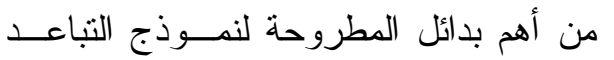

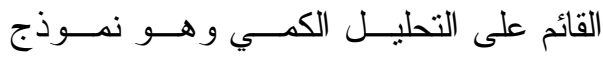

$$
\begin{aligned}
& \text { الاستجابة للتنخل القائم على التحليل الكيفي. }
\end{aligned}
$$

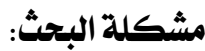

$$
\begin{aligned}
& \text { نشأت مشكلة البحث عنـــما قامــت } \\
& \text { الباحثة بالكثف عن ذوي صعوبات الطلاقــة } \\
& \text { القرائية من تلاميذ المرحلـــة الابتدائيــة، إذ } \\
& \text { قامت بإجر اء دراســة اســنطلاعية لمائــة }
\end{aligned}
$$

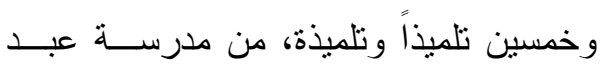

$$
\begin{aligned}
& \text { تعتبر صـــوبات القــراءة جــوهر }
\end{aligned}
$$

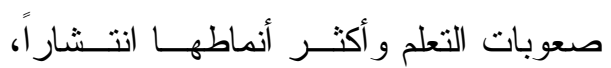

$$
\begin{aligned}
& \text { فالتناميذ ذوو صعوبات تعلم القر اءة يمنلــــون } \\
& \text { الثريحة الكبرى في مجتمع صعوبات التعلم، } \\
& \text { حيث يشير الباحثين إلى أن صعوبات القر اءة }
\end{aligned}
$$

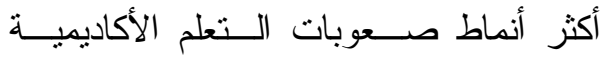

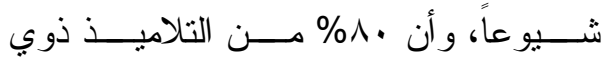

$$
\begin{aligned}
& \text { صعوبات التعلم هم ممن لديهم صعوبات في } \\
& \text { القر اءة (فتحي الزيات، } 1991 \text { (1). } \\
& \text { وفي عام (999)()، حـدد الفريـق } \\
& \text { القومي للقر اءة (NPR) خمـسة مكونــات } \\
& \text { لتعليم القراهة و التي تعد ضـــرورية لتعلــيم }
\end{aligned}
$$

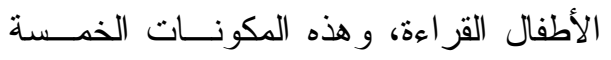

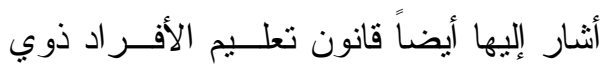

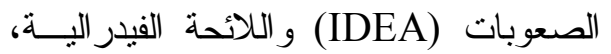

$$
\begin{aligned}
& \text { و هذه المكونات هي الطلاقة القرائية، الفهــ } \\
& \text { القرائي، معاني المفردات و الكلمات، الـــوعي }
\end{aligned}
$$

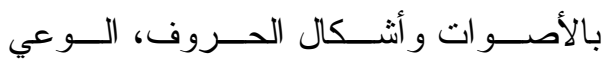

$$
\begin{aligned}
& \text { بالمقاطع و الكلمات، ويكتسب الأطفــال ذوي }
\end{aligned}
$$

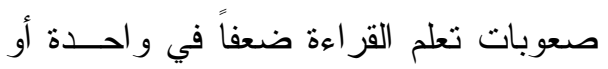


ظل محك التباعد عنه في ظل نموذج

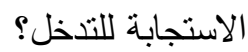

r- هل يوجد أثز دال لبرنامج الاستجابة

للتناخل في علاج الطلاقـــة القر ائيــة

(بأبعادها الثثلاثة لدي ذوي صعوب لإنات

الطلاقة القر ائية؟

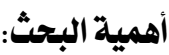

يتيح هذا البحث الفرصة لتقليص نسبة

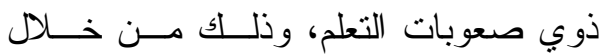

التحديد و التشخيص الدقيق لذوي صــعوبات

التعلم، من خلال نموذج الاستجابة للتـدخل

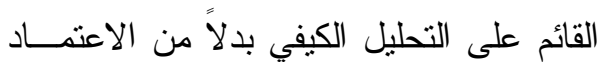
على محك التباعد الذي يحدد نسبة عالية من

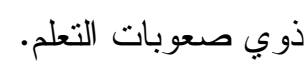

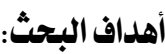

يرهف البحث الحالي إلى تحديد:

ا- مدي فاعلية نموذج الاستجابة للتخل

في تشخيص ذوي صعوبات التعلم.

r- مدي فاعلية نموذج الاستجابة للتنخل

في علاج مهار ات الطلاقة القر ائية.

المفاهيم الإجرائية للبحث:

التعريــف الإجر ائســي لنــــذذج الاســتجابة

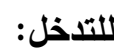

نموذج يقوم على التدخلات التدريسية

الملائمة و العالية الجودة و المكثقة وتتم بشكل

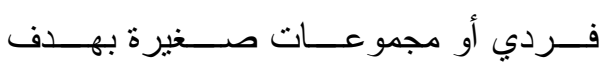

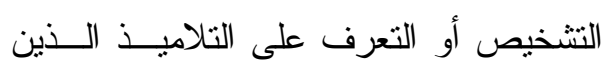

اللطبف البخـــدادي المـششتركة إدارة غــرب

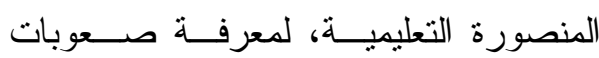

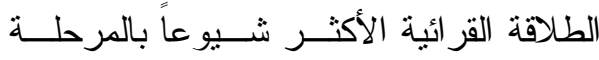

الابتدائية، وقد طبق المعلمون مقاييس التقدير

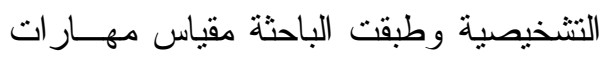

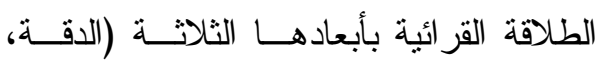

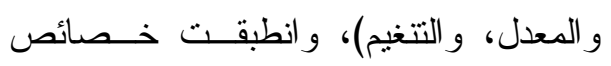

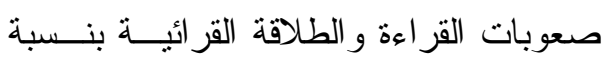

تفوق با \% من تلاميذ العينة الاســنطلاعية،

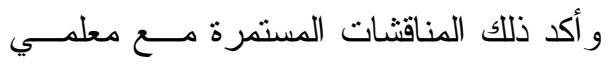
المرحلة الابتدائية.

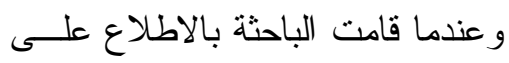

معظم الدراسات السابقة لصعوبات القـــراءة،

وجدت أن الطلاقة القر ائية لم تخضع للار اسة

و البحث في مصر و الوطن العربـي - فــي

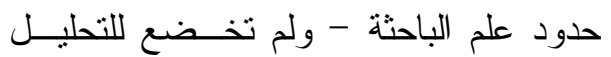

الكيفي ولكن تم تشخيص صعوبات القـــر اءة

من خلال الاعتماد على محك التباعد، الــذي لـالي

يعتمد على درجـات الـــكاء، و التحــصيل

الدراسي، وذلك غير كاف في تحديــــ ذوي

صعوبات التعلم بسبب اهتمامه بالكم، ولــبس ولـيس الكيف.

ومن هنا تأتي الحاجة إلى مشكلة الار اســـة

و التي تتحدد مشكلتها في الأسئلة التالية:

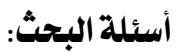

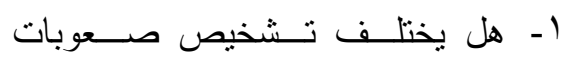

الطلاقة (الدقة، المعدل، التتغيم) فـي في في 
لهذا الإنجاز ، لأنها تعتمد علية، وغالبــا مـــا

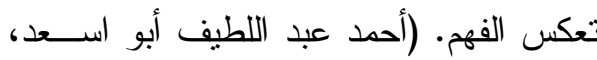

. (Or r t . 0

مفهوم الطلاقة القرائية:

قد عرفت الطلاقة القرائية تعريفـات

متعددة و على كثرتها لا تختلف عن المعنـي لهي

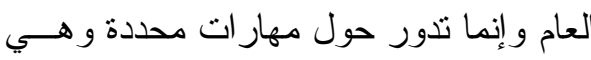

(الدقة، المعدل، النتغيم).

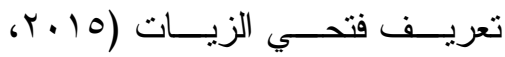

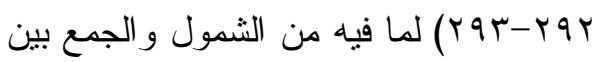

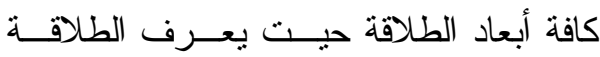
القر ائية: بأنها القدرة على قر اءه الكلمات بدقة وسرعة وعلى نحو آلي ودون جهد، وفضلا عن ذلك تتمل الطلاقة القر ائية:

1ـ القدرة على القراعة التعبيريــة عــن

المعاني المنضمنة فيما يقر ا بما يلائم.

$$
\text { r - ت تتغيم القر اءة فيما يقر أ. }
$$$$
\text { r- معدل القر اعة في وحده الزمن. }
$$

ومن ثم ترتكز الطلاقة القرائية هنــــا

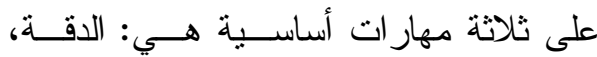
المعدل، التتغيم.

أبعاد الطلاقة القزائية:

مهارات الطلاقة القرائية تتحدد فيما يلي:

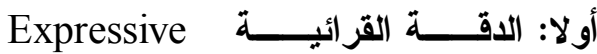
:Reading

الدقة: قدرة القر اء على فــك رمـــوز

النص بدقة. وقد استخدمت اختبار ات القراءة
يعانون من صعوبات في الطلاقة القرائيــة، ومن ثم علاج التلاميذ الذين ثبت أنهم يعانون من صعوبات الطلاقة القرائية، ويقدم النموذج

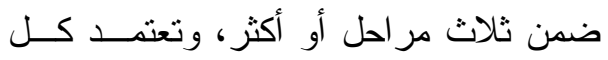
مرحلة على سابقتيها. التعريف الإجر ائي للطلاقة القرائية: تعرف تلاميذ الصف الر ابع و الخامس

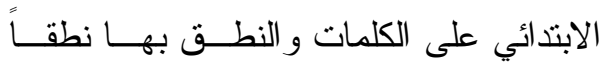

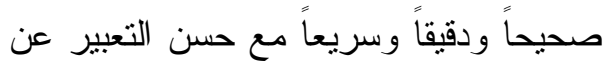
المعاني المتضمنة. الإطار النظري ومصطلحات البحث: صeading Disabilities:صعوبات القراءة تشكل القراءة أحد المحاور الأساسية

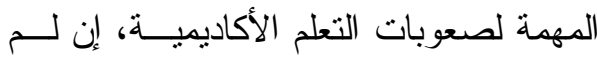

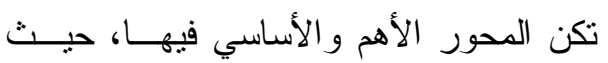

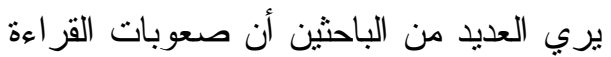
تمثل السبب الرئيسي للفنل الدراسي، فهـي

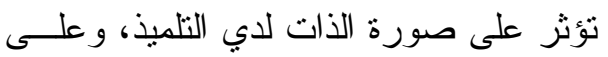
شعوره بالكفاءة الذاتية، وتقوده إلى العديد من أنماط السلوك اللا تو افقي و القلق و الافتقـــار

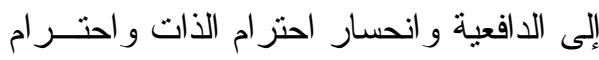

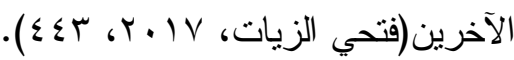

الطلاقة القرائية: بينما كانت الطلاقة عنصر ا مهملاً في السابق، فإنها تتلقى الأن الكثير من الاهنمام،

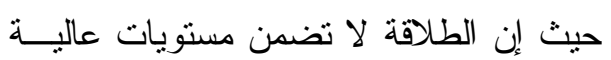
من الإنجاز القرائي فقط بل إنها ضــرورية 


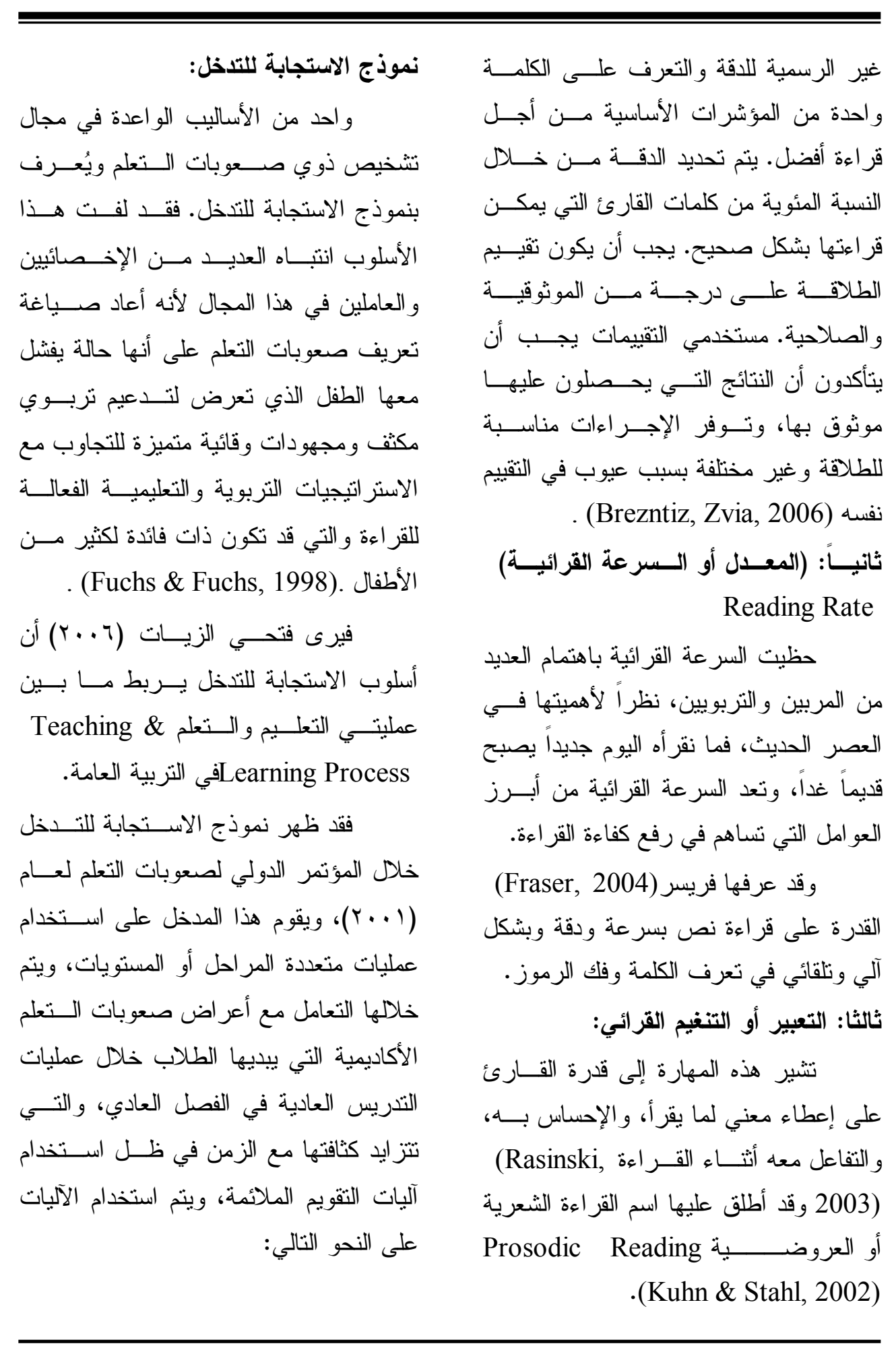


دراسات وبحوث تناولت الطلاقة القرائية:

$$
\begin{aligned}
& \text { دراسة عبد الحليم (9 . . ب): } \\
& \text { هافت الاراسة إلي: }
\end{aligned}
$$

الكثف عن استخدام القر اعة المتكررة

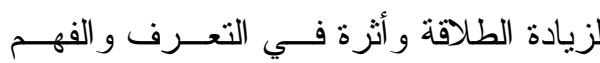

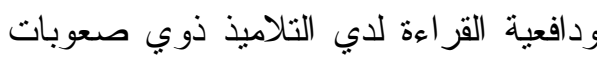

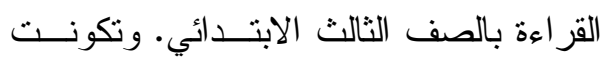

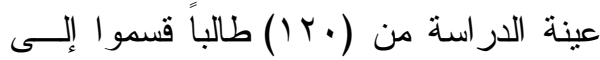

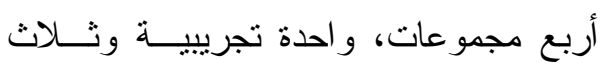

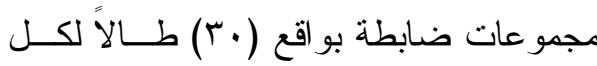

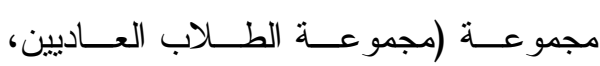
ومتوسطي القراءة ومرتفعي القر اءة). توصلت الدراسة إلى النتائج التالية أهمها: - وجــود فــروق دالــة إحــصائيا بــين المجموعة التجريبية ومجمو عة متوسطي وجي دونين

$$
\text { القر اعة ومرتفعي القر اعة. }
$$

- وجود قروف بين المجموعة الــضابطة و التجريبية في طلاقة القر اءة والتعـرف وند

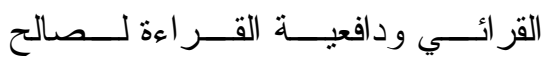
المجمو عة التجريبية.

- عدم وجود فروق بين كل من المجموعة

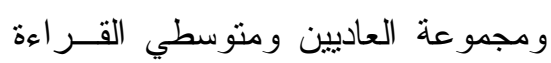
في الطلاقة وزمــن التعــرف ودافعيــة القز اعة.

- وجدت فـروق فـــي الطلاقــة لــصالح

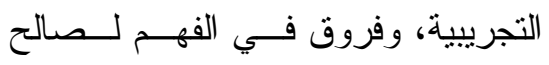
المنوسطين، ووجدت فروق في جميـع وقع

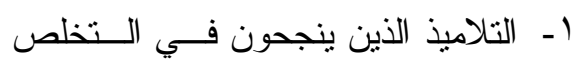

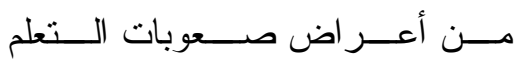

الأكاديمية مع الحد الأدنى للتـخل يــنت

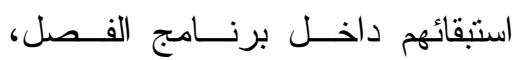

و هؤلاء التلاميذ ليسوا في الأصل من دن برن

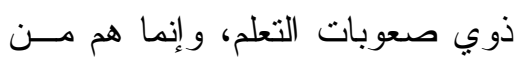

ذوي التقريط التحصيلي لكنهم تداخلوا معهم بسبب خاصية التباعد.

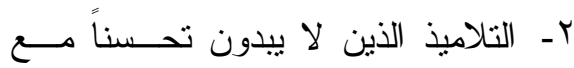

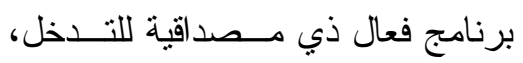

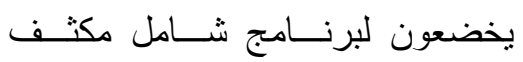

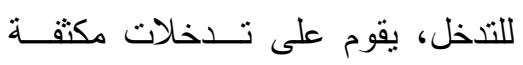
وكافية وملائمة وعالية الجــودة وذات مصداقية تجريبية. r- تخضع عمليـات التــدخل ونتائجــه

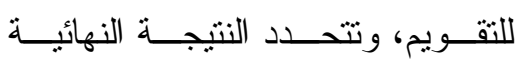
لاعتبار أي من هؤلاء ذوي صعوبات

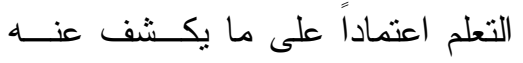

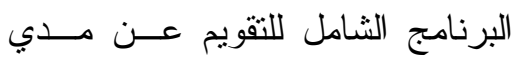

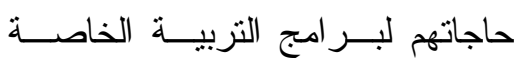

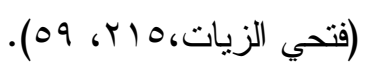

\section{ميزات نموذج الاستجابة للتدخل RTI :}

إن نموذج الاستجابة للتنخل RTI به

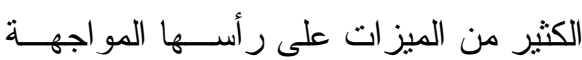
المبكرة من أجل الوقاية أو العلاج بدلا مــن

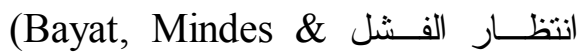
Covitt, 2010; Loftus et al. 2010) 
الطلاب جميعهم، وكذلك ازدادت مسستويات الاستيعاب الحرفي و الاستتناجي. دراسات وبحوث تناولت تثخيص وعـلاج صعوبات القراعة (الطلاقة القرائية) في ظل ونل فئل نموذج الاستجابة للتدخل. دراسة (فتحي الزيات، ج . ب):

هدفت الدراسة إلى معرفــة القيمــة التتبؤية لتحديد وتشخيص صـــوبات الــتعلم بين نماذج التحليل الكمي و التحليل الكيفي. شملت عينة الدراســة علـي(؟ .0) تلاميذ من تلاميذ الصفين الثالـــث و الرابــع الابتدائي من أربع مدارس بمحافظة الدقهلية بجمهورية مصر العربية. توصلت الار اسة إلى ما يلي: 1 - أن محك التباعد القائم علــى التحليــل الكمي لا يميز بين صـــوبات الــتعلم وذوي التفريط التحصيلي. r- أن نماذج التحليل الكمي ومنها نموذج

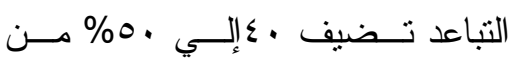

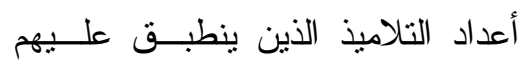

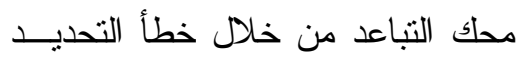
و التشخيص، إلى مجتمــع صـــوبات

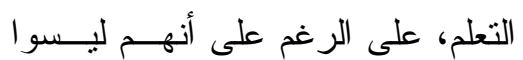

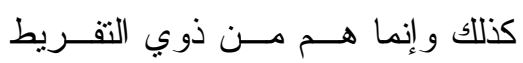
التحصيلي.
المتغيرات لصالح مجموعــة مرتفعـي القراءة، بالإضافة إلى وجود فروق دالة

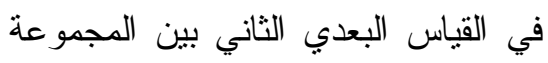
التجريبية و الضابطة في الطلاقة القرائية

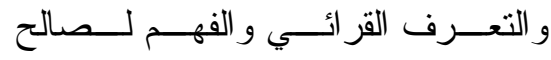

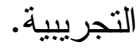

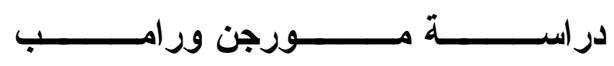

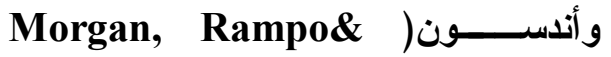
:(Andeson,2007 هدفت الارسة إلي:

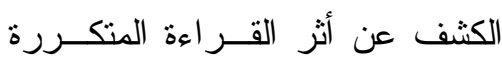

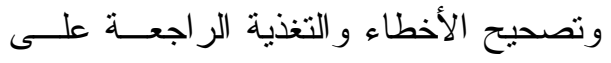

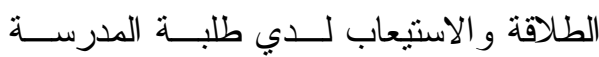
المتوسطة ذوي المشكلات السلوكية. تكونت

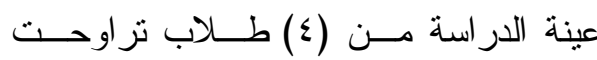

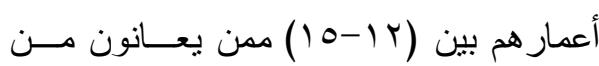

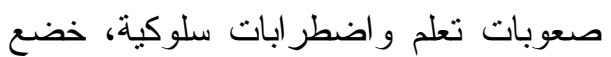

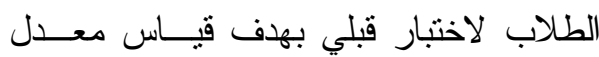

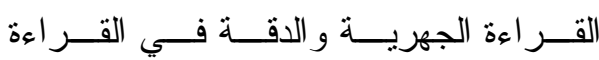

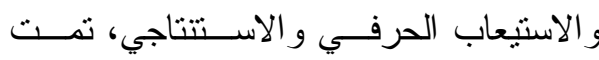
الدراسة على مدار (11) أسبو عاً، تلقي فيها

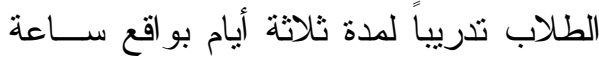

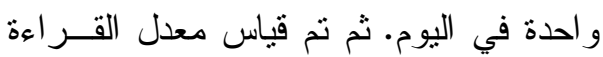
و الدقة من خلال اختبار بعدي. توصلت الدراسة إلى النتائج التالية أهمها: ازدياد معدلات القراءة لدي ثلاثة من

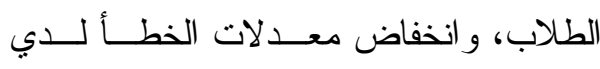


وتلميذة مــن الــصفين الرابــع و الخــامس

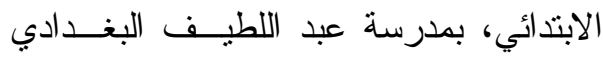

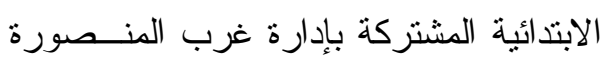

التعليمية.

مرحلة تثخيص عينة البحث:

لتشخيص عينة التلاميذ الذي يعـانون

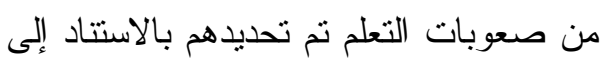

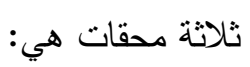

\section{Discrepancy}

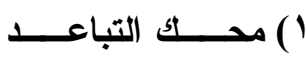

\section{:Criterion}

تم ذلك عن طريق حساب التباعد بين

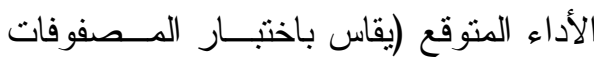

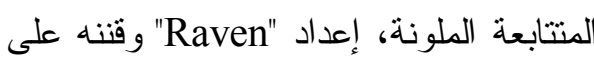
البيئة المصرية عماد أحمد حسسن)، و الأداء الفعلي (يقاس بدرجات تحصيل التلاميذ فــي مادة اللغة العربية

محك الاستبعاد Exclusion Criterion: تم استبعاد عدد (1) تلميذة تعاني من ضعف شديد في السمع مع مشاكل في النطق

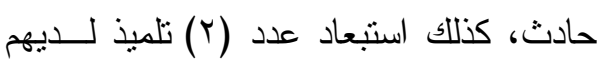
مشاكل اجتماعية، و عدد (Y) تلميـــ لــديهم ضعف في البصر • منس

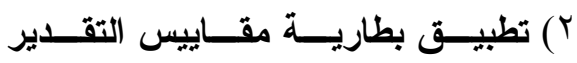

\section{التشخيصية لذوي صعوبات القراعة.}

تم تطبيق ذلك لاستبعاد التلاميذ ذوي

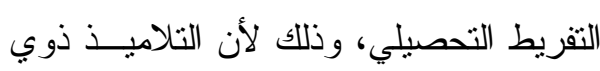
التفريط التحصيلي وذوي صــعوبات الــتعلم

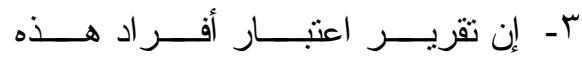

المجموعات من ذوي صعوبات التعلم

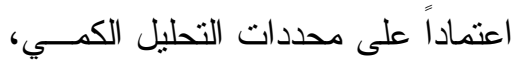

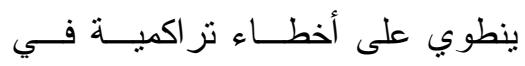

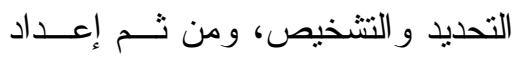

$$
\text { البر امج العلاجية لها. }
$$

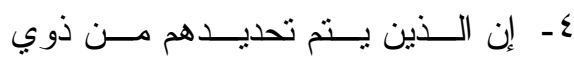

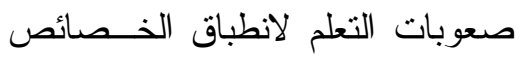
السلوكية لذوي صعوبات التعلم عليهم

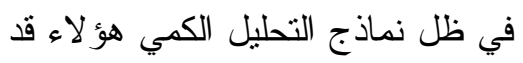

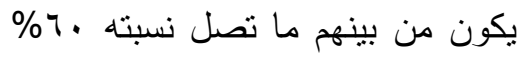

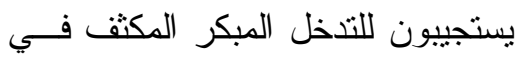

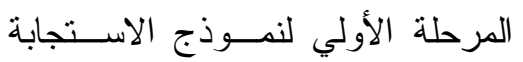

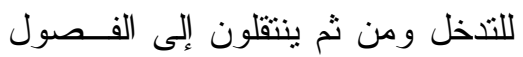
العادية. خار ج مظلة صعوبات التعلم.

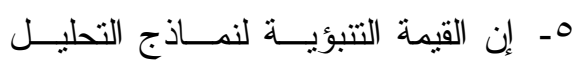
الكيفي أعلي و أدق وذات مــصداقية، لـاتية مقارنة بنماذج التحليل الكمي القائمــة على التباعد ومعدلاته الكمية.

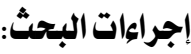

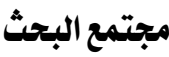

تمنل مجتمع البحث في التلاميذ ذوي

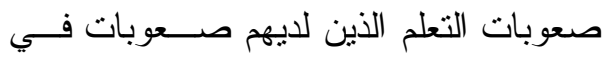
القر اءة بالصفين الرابع والخــامس الابتدائي في جمهورية مصر العربية

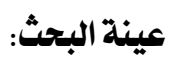
ثانياً: عينة البحث الأساسية: تكونت عينة البحث قبل تحديــــ ذوي

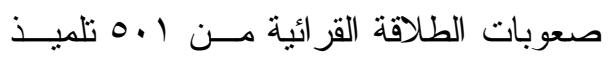


خارج عينة الدر اسة، بهدف حساب الاتــساق الداخلي و الثبات:

$$
\text { ( ) حساب الاتساق الداخلي }
$$

تم حساب صدق الاتــساق الــداخلي

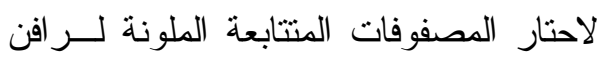

بعد تطبيقه على عينة عشو ائية عددها (•ـ)

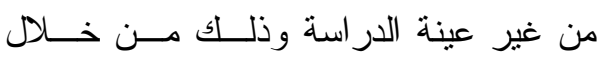

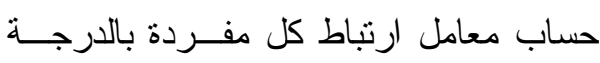
الكلية للاختبار •

قد تم حساب ثبات المقياس بمعادلة

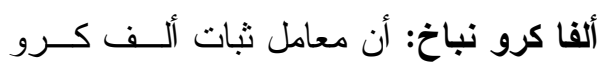

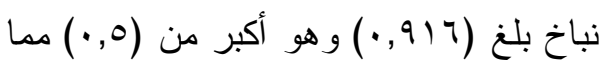
يدل علي ثبات اختيار المصفوفات المتتابعــة وهن الملونة لر افن.

ثانيا: مقاييس التقدير التشخيصية لصعوبات

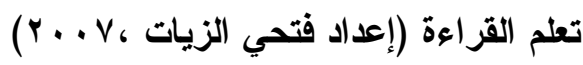
وفيما يلي الخصائص السيكو مترية لبطارية مقاييس التقدير التشخيصية الخاصة بعينــة البحث الحالي:

تم تطبيق المقياس على (• • ت) تلميــذ

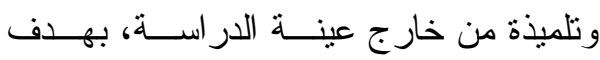

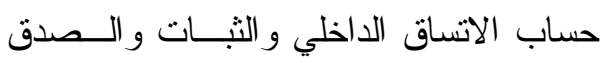

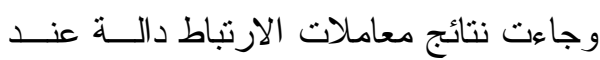

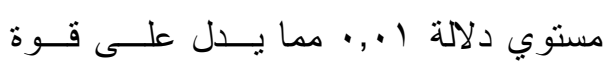

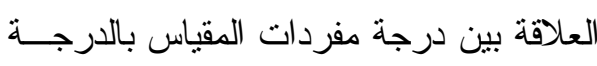

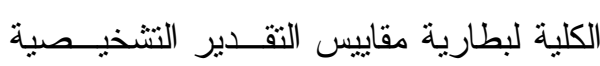

يشتركون في أن ذكاءهم متوســـ أو فــوق المتوسط وتحصيلهم الدر اسي منخفض.

وبعد تطبيق الباحثة مقياس الطلاقـــة

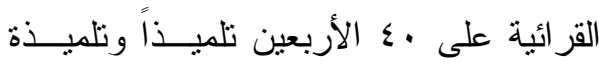

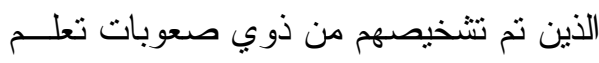
القراءة خلصت الباحثة أن هناك ثمانية تلاميذ دوي وتلميذات ممن يعانون من صعوبات الطلاقة القر ائية.

$$
\text { أدوات البحث ومواده: البه: }
$$

استخدمت الباحثة الأدوات التالية:

( ) اختبار المصفوفات المتتابعة الملونـــة لر افن (تقنين عمــاد أحمــد حسـن،

$$
\text { (r.) }
$$

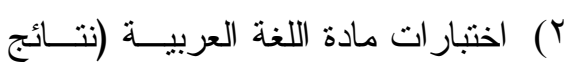

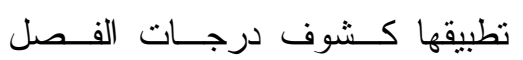

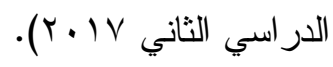

ץ) مقاييس الثقدير التشخيصية لصعوبات

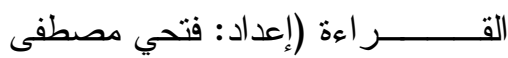

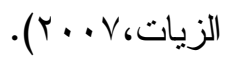

؛) مقياس الطلاقـــة القرائيــة (إعـــاد:

$$
\text { الباحثة). }
$$

0) القطع القرائية المختارة.

$$
\text { 7) برنامج البحث. }
$$

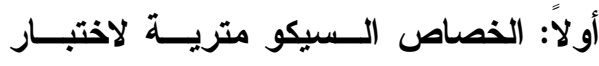

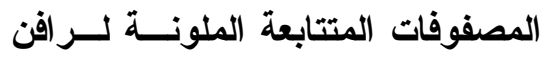
الخاص بعينة الدراسة: تم تطبيق اختبار المصفوفات المنتابعة

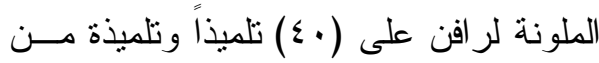


العربية ومن خبر اء المجال مسـن المعلمـين

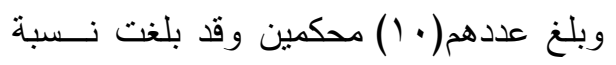

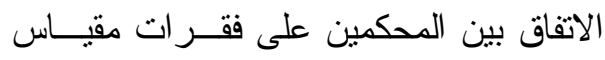

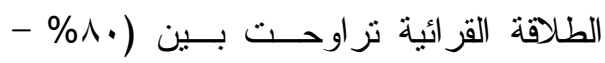

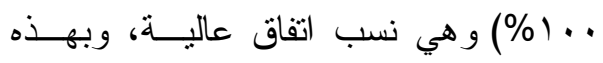

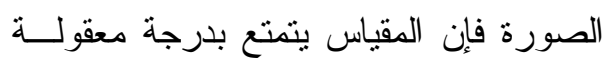

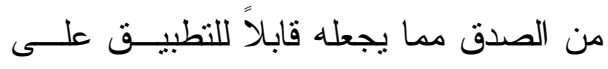
تلاميذ الصف الر ابع و الخامس الابتدائي. وقد تم تطبيق المقيــاس علــى (0.

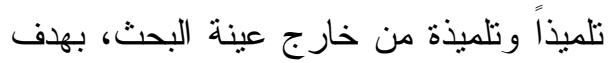
حساب الاتساق الداخلي و الثبات: ب) حساب الاتساق الداخلي تم حساب صدق الاتــساق الـــداخلي للمقياس بعد تطبيقه علـى عينـــة عـشـوائية

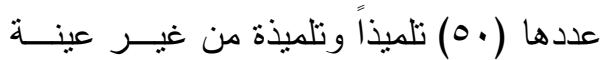

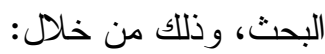

- - حساب معامل ارتباط درجة كل مفردة بالدرجة الكلية للبعد المنتمية إليـهـ: تم حساب معاملات ارتباط درجة كل مفردة بالدرجة الكلية للبعد التي تتنمي

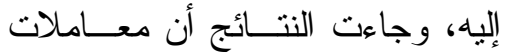

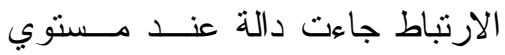
دلالة ا.,. • مما بدل على قوة العلاقة بين درجة مفردات المقياس بالدرجـة

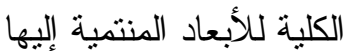
- - حساب معامل ارتباط درجة كل بعــ بالدرجة الكلية للمقياس

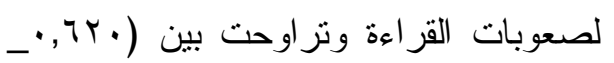
$\cdot(\cdot, 9+4$

ثالثاً: مقياس مهــارات الطلاقِــة القرائيــة (إعداد: الباحثة). الهـف من المقياس قامت الباحثة بإعداد هـــا المقيــاس لقياس مهار ات الطلاقـــة القرائيـــة الــثناثل

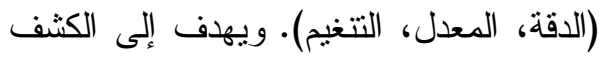
المبكر عن التلاميذ ذوي صعوبات الطلاقـــة

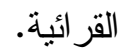
وصف المقياس تضمن المقياس ثلاث مهار ات رئيسية هي: الدقة، المعدل، التتغيم. تتدرج أسفل كل

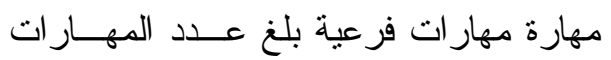
الفرعية ؟0 مهارة.

• يندرج تحت مهارة الدقة اب مهارة

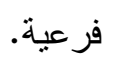

• ويندرج تحت مهارة المعسل 19

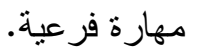

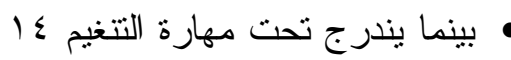
مهارة فرعية. الخصائص السيكو مترية للمقياس: أ) صدق المحكمين:

تم عرض المقيــاس فـي صــورته

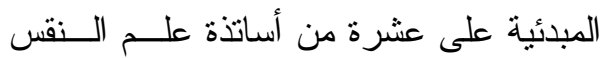
التزبوي، و المناهج وطرق تــدريس اللغـــة 
تتمثل إجراءات التطبيق الميداني فيما يلي:

1 - اختارت الباحثة عينة البحث من تلاميذ

الصف الرابــع و الخــامس الابتــــئي

بمدرسة عبد اللطيف البغدادي الابتدائية

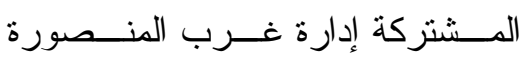

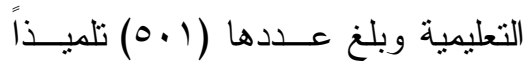

وتلميذة.

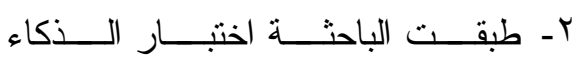

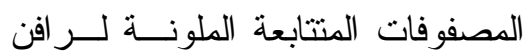

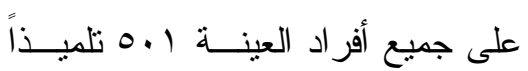

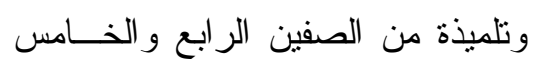

$$
\text { الابتدائي. }
$$

r- استخدمت الباحثة الذكاء، و التحــصيل

العام في اللغة العربية، و التحصيل في

اختبار القراءة من قبل المعلمة لحساب

التباعد بين الذكاء و التحصيل، و استبعاد

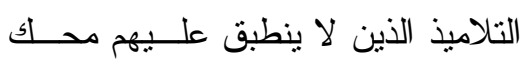

$$
\text { التباعد. }
$$

ع - تحديد التلاميذ الذين لديهم صعوبات في

القر اعة من خلال محك التباعد، بلغـــت

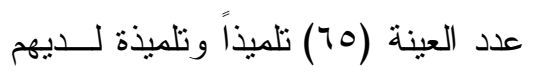

تباعد بين الذكاء و التحصيل.

هـ طبقت مقــاييس التقــدير التشخيــصية

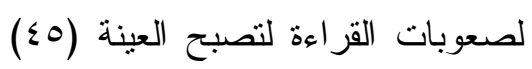

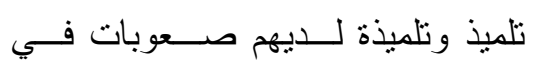

$$
\text { القر اءة. }
$$

7- طبقت الباحثة مقياس الطلاقة القرائيــة على (0؛ ) تلميذ وتلميذة ممـن لـديهر
للتأكد من صدق التكــــين الفرضــي

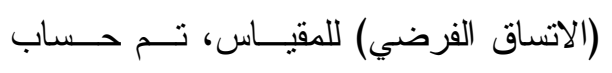

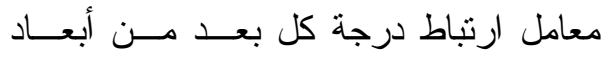

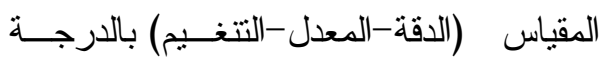

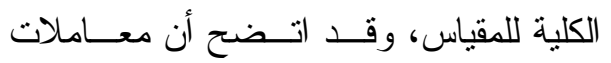

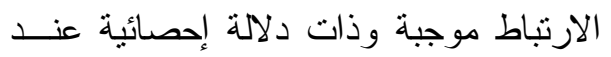

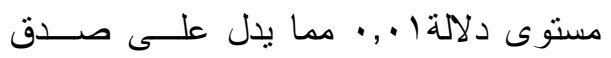
الاتساق الداخلي للمقياس.

ج) حساب ثبات المقياس بمعادلة ألفـــا

كرونباخ

تم حساب ثبات المقياس بطريقة ألفــا

وبلغت معاملات الثبات لأبعاد المقياس جاءت لمبات بطربة

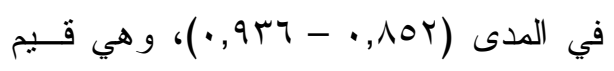

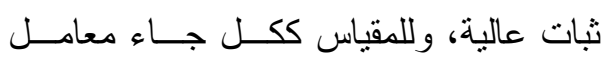

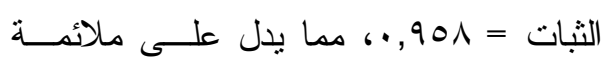

$$
\text { المقياس لأغر اض البحث. }
$$

د) صـــق المحــــ لمقيــاس الطلاقـــة

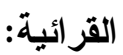

أن جميع معــاملات ارتبـــاط أبعـاد

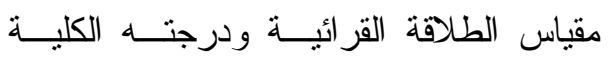

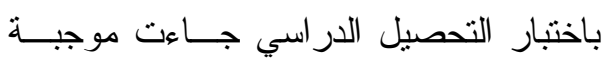

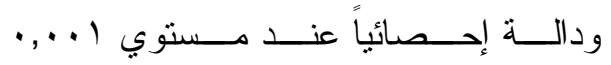

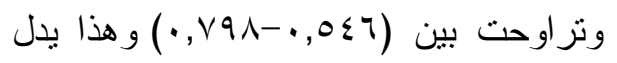

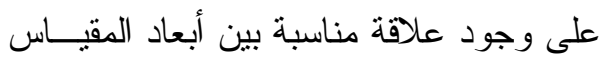
و التحصيل الدراسي.

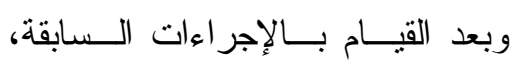

أصبح مقيــاس الطلاقـــة القرائيــة صـــالحاً للنطبيث 
الجلسة الواحدة • ب دقيقة، كــان هــــا

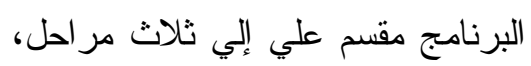

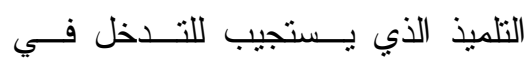
المرحلة الأولي يخــرج مسـن مظلـــة صعوبات التعلم وينتلل مع زملائه في الفصل، و الذي لا يستجيب ينتقل إلـي ولي في

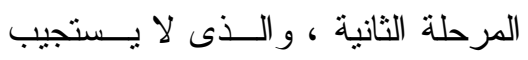

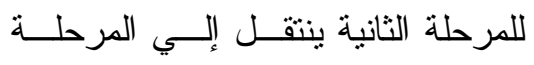

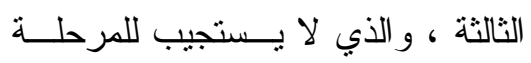
الثالثة ينتقل إلي التزبية الخاصة.

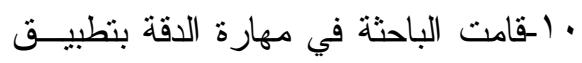

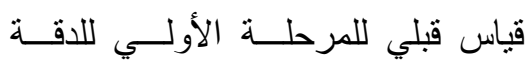
وتحديد نقاط القوة و الضعف لكل تلميذ

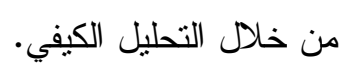
الـثم قامت بالتدخل المناسب من خــلال الجلسات الفردية لكل تلميذ علي حــده

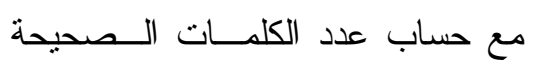
الذي يسنطيع كل تلميذ قر أتها في بداية

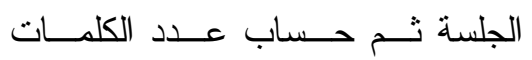

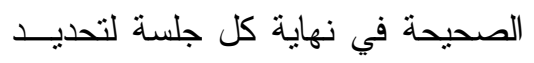

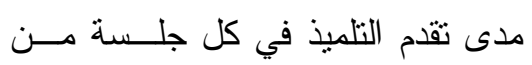

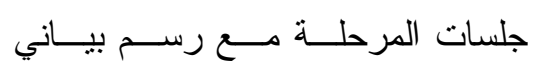
لمستوي التقدم في كل جلسة.

r إمامت الباحثة بتطبيق قياس بعـدي (1)

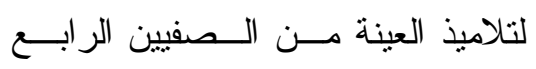

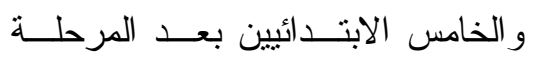

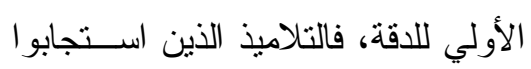

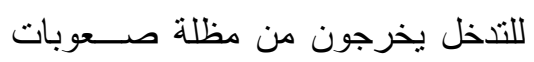

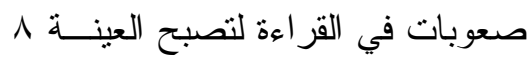

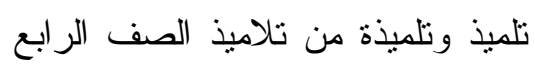

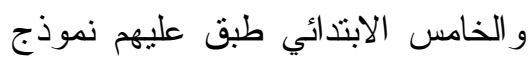
الاستجابة للتنخل. V- قامت الباحثة بنطبيق القبــاس القبلــي

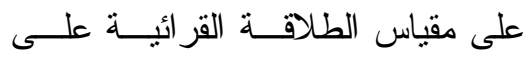
التلاميذ ذوي صعوبات الطلاقة القر ائية

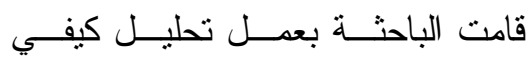

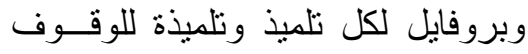
وتحديد نقاط القوة و الضعف. 1ـ قامت الباحثة في ضوء هــــا التحليـلـل

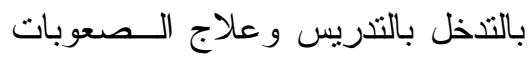

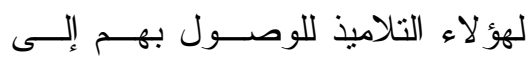

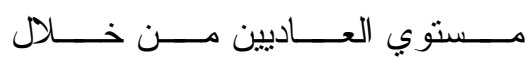
استر اتيجيات الطلاقة القر ائية. 9 - نطبيق البرنامج التشخيصي العلاجسي

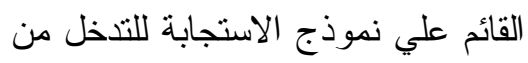
خلال التحليل الكيفي لكل تلميذ وتلميذة من التلاميذ ذوب صـــعوبات الطلاقـــة القر ائية بحسب حاجة كل تلميذ وتلميذة

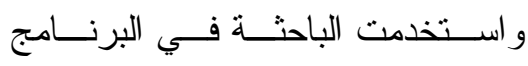

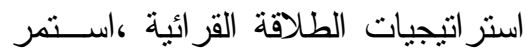

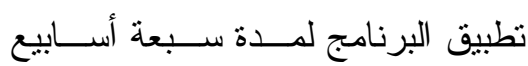
بو اقع ثلاث جلسات لكل تلميذ يوميــاً

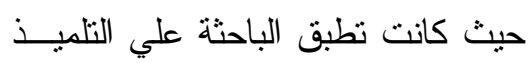

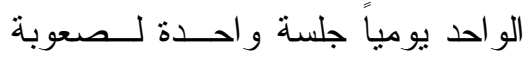

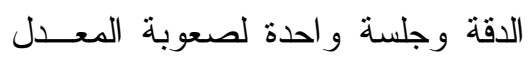

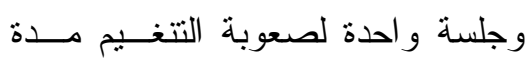




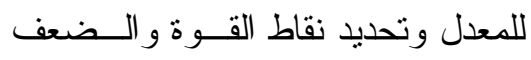
لكل تلميذ من خلال التحليل الكيفي.

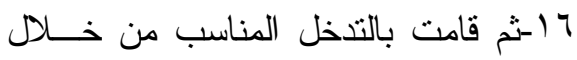

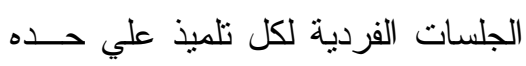
مع حساب عدد الكلمـات الــصحيحة

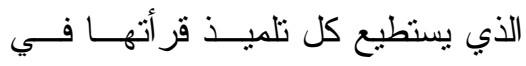

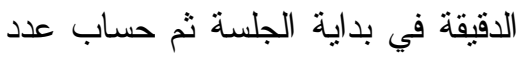
الكلمات الصحيحة الذي يستطيع التلميذ قر أتها في الدقيقة الواحدة في نهاية كل

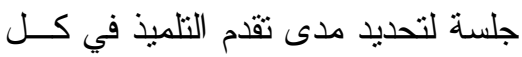

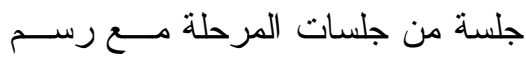
بياني لمستوي التقدم في كل جلسة. ا ا-قامت الباحثة بتطبيق قياس بعـدي (1)

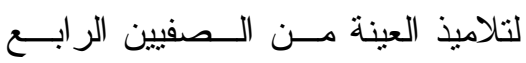

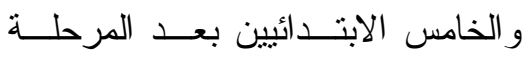
الأولي للمعدل، فالتلاميذ الذين استجابوا

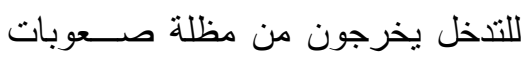
المعدل وينتقلون إلى الفصل مع أقر انهم

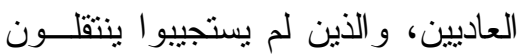

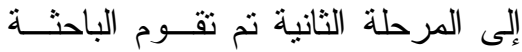
بالتــــل مــرة أخــرى مـــع تغييــر الاستر اتيجيات المستخدمة في المرحلة الأولي.

1 اـقامت الباحثة بعد انتهاء المرحلة الثانية بتطبيق قياس بعدي(r)، فالتلاميذ الذين

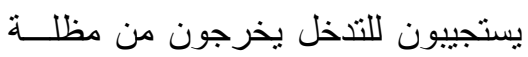

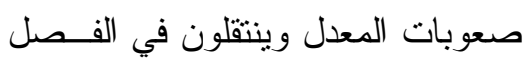
مع أقر انهم العاديين و الذين لم يستجيبو المعات
التعلم وينتقلون إلى الفصل مع أقر انهم

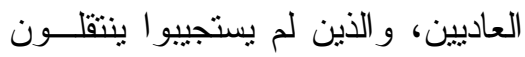

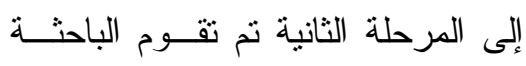
بالتــــخل مــرة أخــرى مـــع تغييــر الاستر اتيجيات المستخدمة في المرحلة الأولي.

با ـقامت الباحثة بعد انتهاء المرحلة الثانية بتطبيق قياس بعدي(؟)، فالتاميذ الذين يستجييون للتندل يخرجون من مظلـــــة

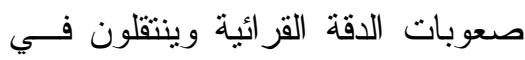

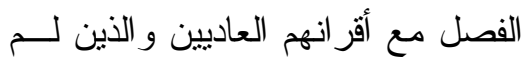
يستجييو ا ينتقلون إلى المرحلة الثالثة نم

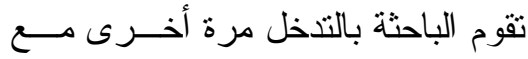
تغيير الاستر اتيجيات المـستخدمة فــي بلهي المرحلة الثانية.

ـ اـقامت الباحثة بعد انتهاء المرحلة الثالثة بتطبيق قياس بعدي(ب)، فالتلاميذ الذين يستجييون للتندخل يخرجون من مظلـــــة

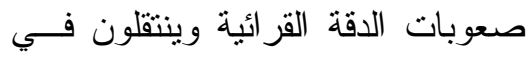
الفصل مع أقر انهم العاديين، و الذين لم

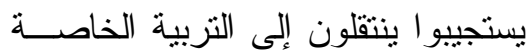

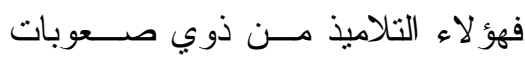

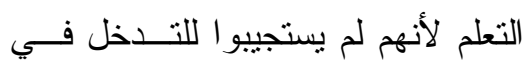

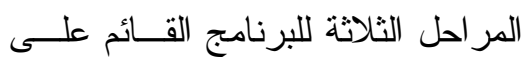
نموذج الاستجابة للتنخل.

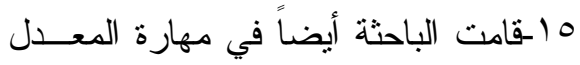
بتطبيق قياس قبلي للمرحلــة الأولـي في في 


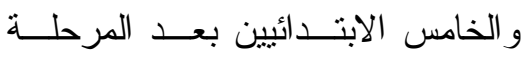

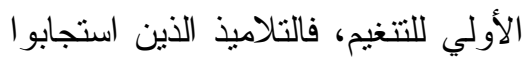

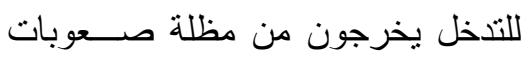
التتغيم وينتقلون إلى الفصل مع أقرانهم

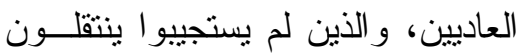
إلى المرحلة الثانية تم تقــوم الباحثــة بالتــــل مــرة أخــرى مـــع تغييـــر الاستر اتيجيات المستخدمة في المرحلة

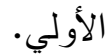

rr-قامت الباحثة بعد انتهاء المرحلة الثانية بتطبيق قياس بعدي(r)، فالتلاميذ الذين

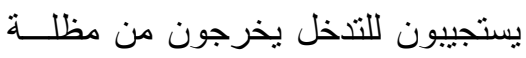

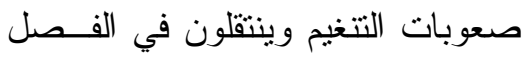
مع أقر انهم العاديين و الذين لم يستجيبوا

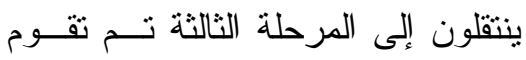
الباحثة بالتدخل مرة أخرى مع تغييــر

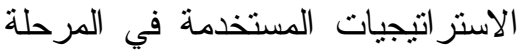
الثانية.

ـ ז-قامت الباحثة بعد انتهاء المرحلة الثالثة بتطبيق قياس بعدي(؟)، فالتلاميذ الذين

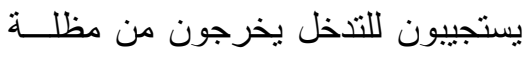

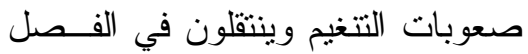

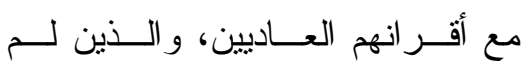

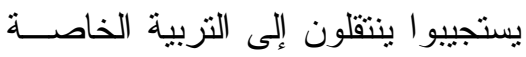

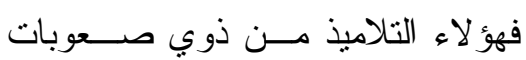

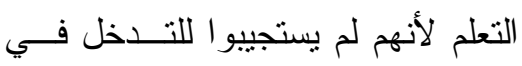

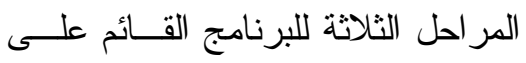

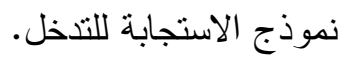

ينتقلون إلى المرحلة الثالثة تــــ تقــوم الباحثة بالتخخل مرة أخرى مع تغييــر الاستر اتيجيات المستخدمة في المرحلة

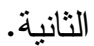

9 اـقامت الباحثة بعد انتهاء المرحلة الثالثة بتطبيق قياس بعدي(ب)، فالتلاميذ الذين يستجييون للتنخل يخرجون من مظلــــة

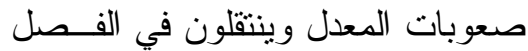

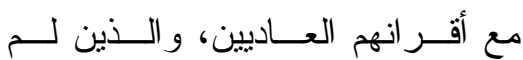
يستجييو ا ينتقلون إلى التربية الخاصــة

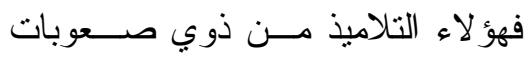

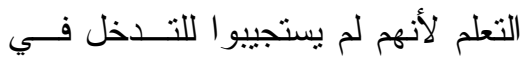

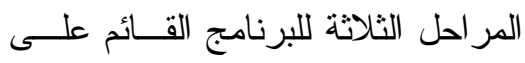
نموذج الاستجابة للتنخل. •r-بامت الباحثة أيضاً في مهارة التتغــيم

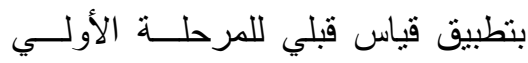

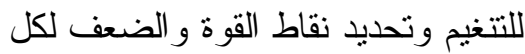
تلميذ من خلال التحليل الكيفي. ابrثم قامت بالتذخل المناسب من خــلال

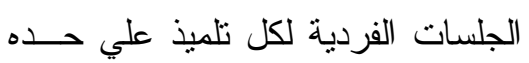
مع حساب درجات التلميذ على بطاقــة الملاحظة لمهــارة التتخـيم (إعــاد:

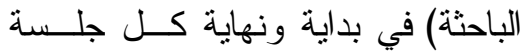

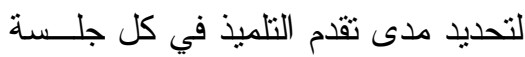

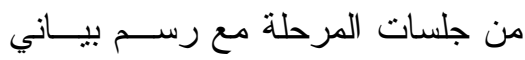
لمستوي التقام في كل جلسة.

r r-قامت الباحثة بتطبيق فياس بعـدي (1)

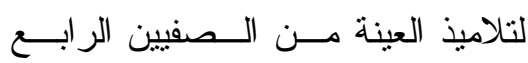


نتائج البحث وتفسيرها:

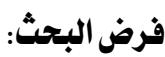

يوجد أثر دال لبرنــامج الاســتجابة

للتلذل في علاج الطلاقة القرائيــة (الدقـــة

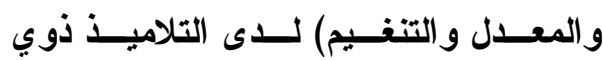
صعوبات الطلاقة القرائية.

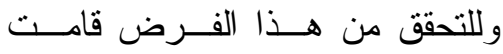
الباحثة بمقارنة أداء كل تلميذ علــي مقيــاس

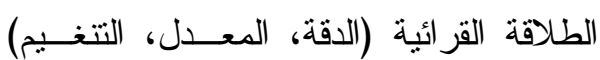
وأسفر ذلك عن بيانات الجداول التالية: roro

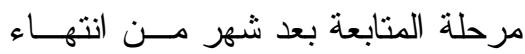
التطبيق، لمعرفة التلاميذ الذين انخفض

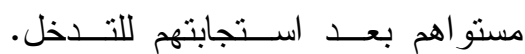
فالتلاميذ ذوو صعوبات التعلم هم الذين

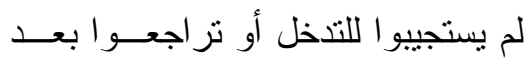
تطبيق القياس البعدي وبذلك تتم أحالتهم التهر للتربية الخاصة، ويصنفون باعتبـار هم

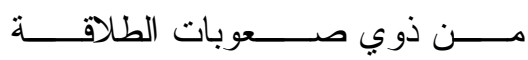
القر ائية.

جدول (1)الفروق بين الرتب في القياسات المتعدة وقيمة كابلاقةة القرائية

\begin{tabular}{|c|c|c|c|c|}
\hline كاץ & متوسط الرتب & متوسط الدرجات & المرادل - ل المل & المتغيرات \\
\hline \multirow{4}{*}{ مستوي • • بالة عند } & 1,19 & $1, \lambda 4$ & القياس القبلي & \multirow{4}{*}{ الألتلميذ } \\
\hline & $r, Y \varepsilon$ & $r, \wedge$. & القياس البعدي للمرحلة الأولي & \\
\hline & $r, Y \varepsilon$ & $r, \lambda$. & القياس البعدي للمرحلة الثانية & \\
\hline & $r, Y \varepsilon$ & $r, \Lambda$. & القياس البعدي للمر طلة الثالثة & \\
\hline \multirow{4}{*}{ 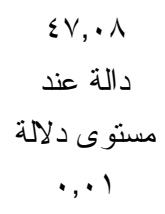 } & 1,59 & 1,19 & القياس القبلي & \multirow{4}{*}{ للتلميذ الثاني } \\
\hline & $r, r r$ & $1,9$. & القياس البعدي للمرحلة الأولي & \\
\hline & $r, 19$ & $r, \leqslant 4$ & القياس البعدي للمرحلة الثانية & \\
\hline & $r, 19$ & $r, \varepsilon V$ & القياس البعدي للمر حلة الثالثة & \\
\hline \multirow{4}{*}{ 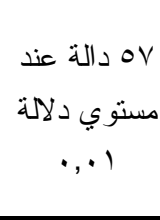 } & $1,1 \varepsilon$ & $r$ & القياس القبلي & \multirow{4}{*}{ اللتلميذ الثالث } \\
\hline & $r, 90$ & $r, .9$ & القياس البعدي للمر حلة الأولي & \\
\hline & $r, 90$ & $r, .9$ & القياس البعدي للمرحلة الثانية & \\
\hline & $r, 90$ & $r, .9$ & القياس البعدي للمر حلة الثالثة & \\
\hline \multirow{4}{*}{ 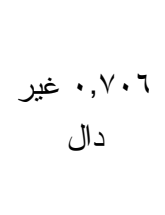 } & $r, \varepsilon$. & . , vo & القياس القبلي & \multirow{4}{*}{ الدرة للتلميذ } \\
\hline & $r, 0$. & $\cdot, \wedge \ldots$ & القياس البعدي للمر حة الأولي & \\
\hline & $r, \tau$ & .,A .. & القياس البعدي للمرحلة الثانية & \\
\hline & r,o. & $\cdot, \wedge$. & القيس البعدي للمرحلة الثالثة & \\
\hline
\end{tabular}




\section{يتضح من الجدول السابق(1):}

أن قيمة كا؟ دالة عند مستوي دلالة بمر احله الثناثة في بعد الدقة ويوضح ذلك

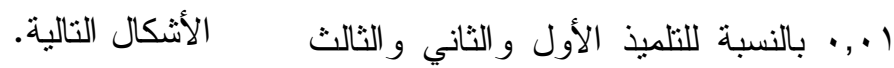

مما يشير لوجود فروق بين القياسات لتحديد اتجاه الدلالة بين متوسطات

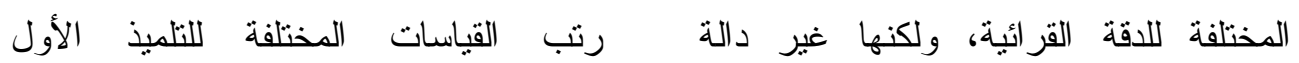
بالنسبة للتلميذ الرابع مما يشير لعدم وجود استخدمت الباحثة أسلوب بوتفيروني للمقارنة فروق في القياسات المختلفة للاقة القرائية بين القياسات المختلفة في بعد الدقة القرائية

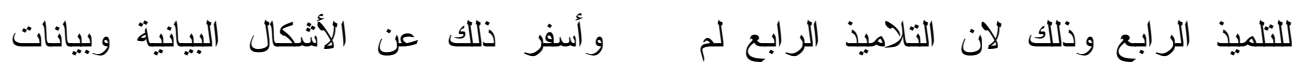
يجتاز البرنامج القائم علي الاستجابة للتنخل الجدول التالي:

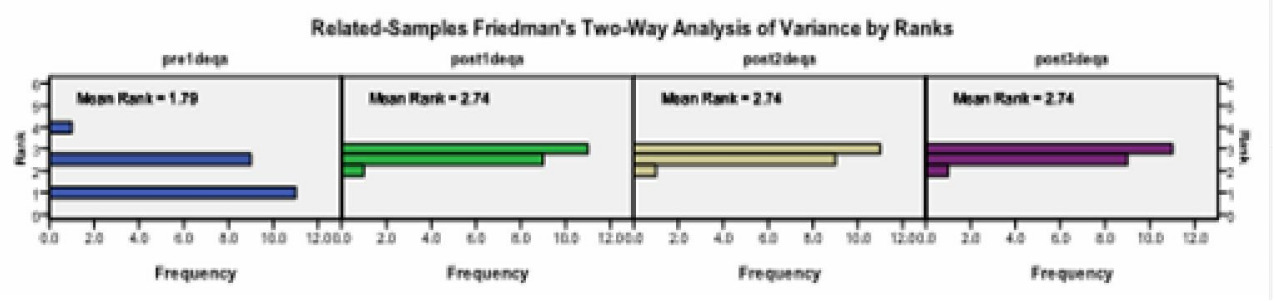

Pairwise Comparisons

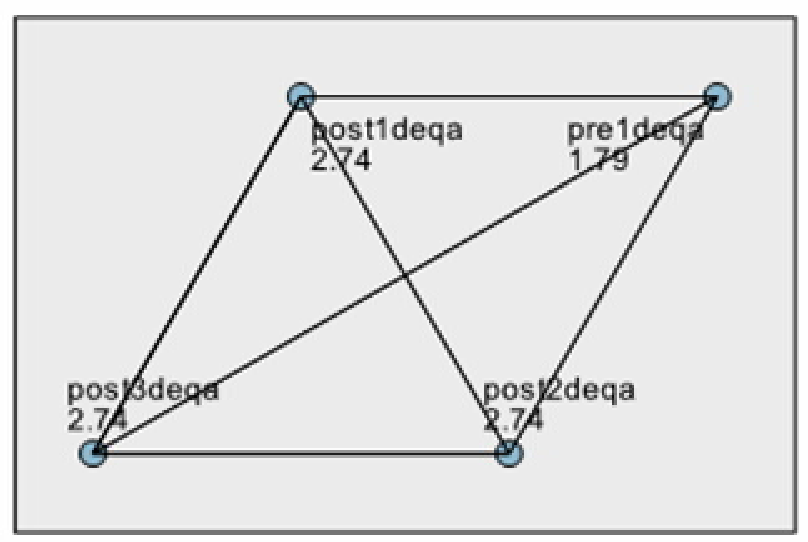

شكل (1) رسم بياني يوضح أثار التدخل على متغير الاقة في القياسات المختلفة للتلميذ الأول 
جدول (ץ) المقارنة بين كل زوج من متوسطات القياسات المتكررة لبعد الدقة للتلميذ الأول

\begin{tabular}{|c|c|c|}
\hline الالالة & الفروق بين المتوسطات & مجموعات المقارنة \\
\hline$\cdot, \cdot 1$ &., $90 \mathrm{r}-$ & قبلي المرحلة الأولي/ بعدي المرحلة الأولي \\
\hline.,$\cdot 1$ &., $90 Y-$ & قبلى المرحلة الأولى/ بعدي المرحلة الثانية \\
\hline$\cdot, \cdot 1$ & $\cdot, 90 \mathrm{r}-$ & قبلي المرحلة الأولي/بعدي المرحلة الثالثة \\
\hline 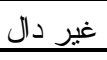 & صفر & بعدي مرحلة أولى/ بعدي مرحلة ثانبة \\
\hline 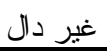 & صفر & بعدي مرحلة أولي/ بعدي مرحلة ثالثة \\
\hline غير دال & صفر & بعدي مرحلة ثانية/بعدي مرحلة ثالثة \\
\hline
\end{tabular}

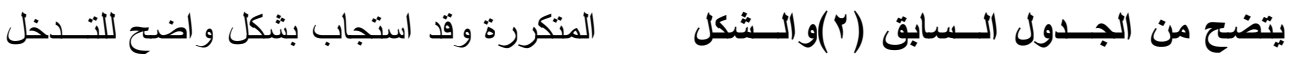

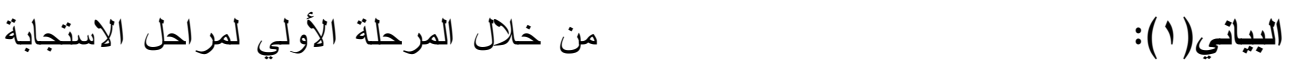
أنه توجد فروق دالة بين مجموعـات

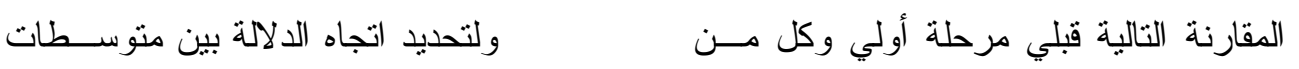

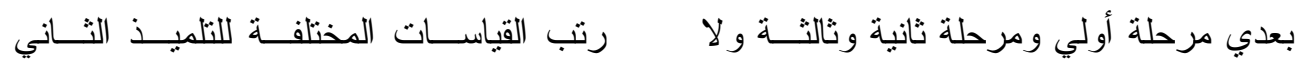

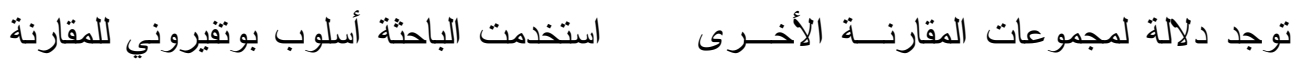

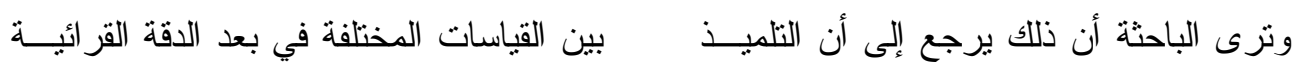

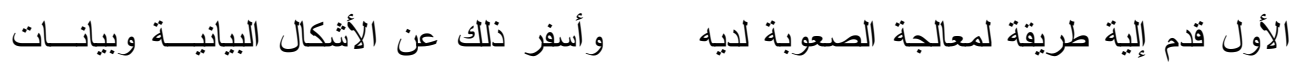

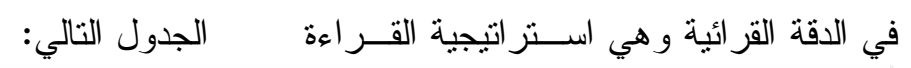

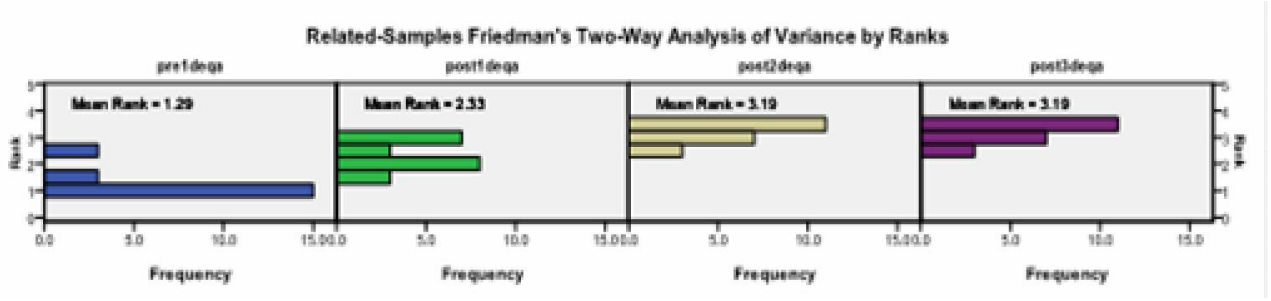

Pairwise Comparisons

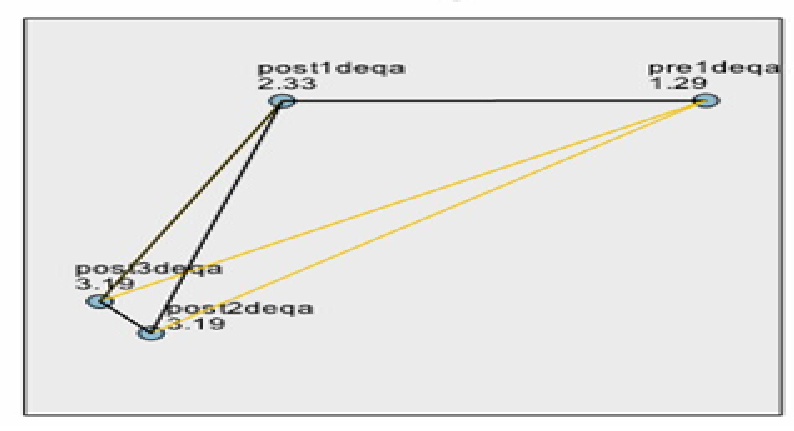

شكل (r) رسم بياني يوضح أثار التذخل على متغير الاقة في القياسات المختلفة للتلميذ الثاني 
جدول (r) المقارنة بين كل زوج من متوسطات القياسات المتكررة لبعد الاقة للتلميذ الثاتي

\begin{tabular}{|c|c|c|}
\hline 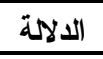 & الفروق بين المتوسطات & مجموعات المقارنة \\
\hline 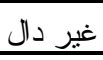 & $1, \cdot \varepsilon-$ & قبلى المرحلة الأولى/ بعدي المرحلة الأولى \\
\hline$\cdot, \cdot 1$ & $1,9 \cdot-$ & قبلي المرحلة الأولي/بعدي المرحلة الثانية \\
\hline., .1 & $1,9 \cdot-$ & قبلى المرحلة الأولى/بعدي المرحلة الثالثة \\
\hline غير دال & $\cdot$, , $0-$ & بعدي مرحلة أولي/ بعدي مرحلة ثانية \\
\hline 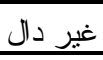 & $\cdot$, , $0-$ & بعدي مرحلة أولى/بعدي مرحلة ثالثة \\
\hline 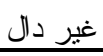 & صفر & بعدي مرحلة ثانية/بعدي مر حلة ثالثة \\
\hline
\end{tabular}

يتضح من الجدول (r) والثكل البياني السابق(r):

المرحلة الأولي لمر احل الاستجابة للتنخل وقد

استجاب للتنخل من خلال المرحلة الثانية.

ولتحديد اتجاه الدلالة بين متوسطات

رثب القياسات المختلفة للتلميذ الثالث

استخدمت الباحثة أسلوب بوتقيروني للمقارنة

بين القياسات المختلفة في بعد الدقة القرائية

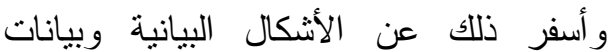

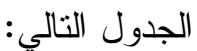

أنه توجد فروق دالة بين مجموعات

المقارنة التالية قبلي مرحلة أولي وكل من

بعدي مرحلة ثانية وثالثة ولا توجد دلالة

لمجموعات المقارنة الأخرى ونرى الباحثة

أن ذلك يرجع إلى أن التلميذ الثاني قدم إلية

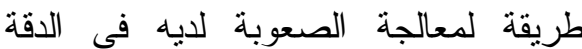
القرائية وهي استر اتيجية القراءة المتكررة ولم يستجب بشكل و اضح للتنخل من خلال

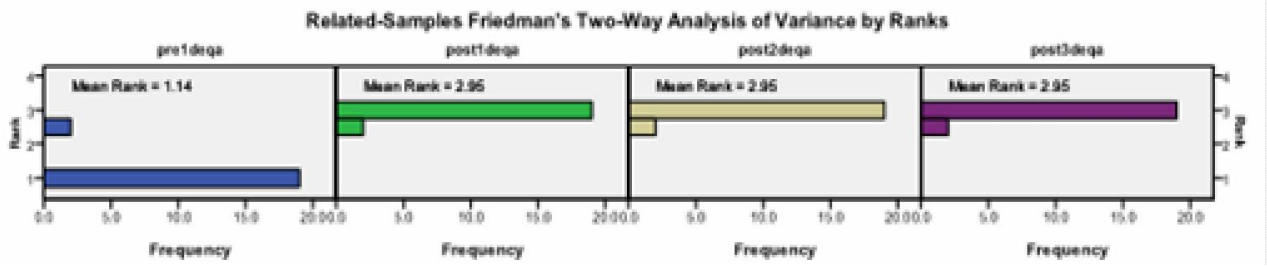

Pairwise Comparisons

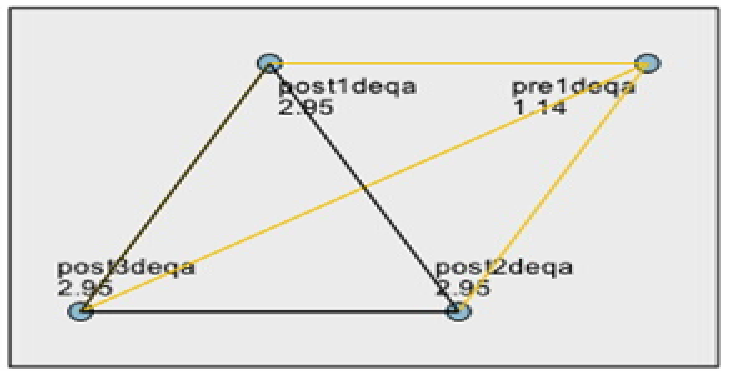

شكل (؟) رسم بياني يوضح أثار التذخل على متغير الدقة في القياسات المختلفة للتلميذ الثالث 
جدول ( ؛) المقارنة بين كل زوج من متوسطات القياسات المتكررة لبعد الدقة للتلميذ الثالث

\begin{tabular}{|c|c|c|}
\hline الدلالة & الفروق بين المتوسطات & مجموعات المقارنة \\
\hline.,$\cdot 1$ & $1, \Lambda 1-$ & قبلي المرحلة الأولى/ بعدي المرحلة الأولى \\
\hline., .1 & $1, \wedge 1-$ & قبلي المرحلة الأولى/ بعدي المرحلة الثانية \\
\hline$\cdot, \cdot 1$ & $1, \wedge 1-$ & قبلي المرحلة الأولي/ بعدي المرحلة الثالثة \\
\hline غير دال & صفر & بعدي مرحلة أولي/بعدي مرحلة ثانية \\
\hline غير دال & صفر & بعدي مرحلة أولى/ بعدي مرحلة ثالثة \\
\hline غير دال - - مال & صفز & بعدي مرحلة ثانية/بعدي مرحة ثالثة \\
\hline
\end{tabular}

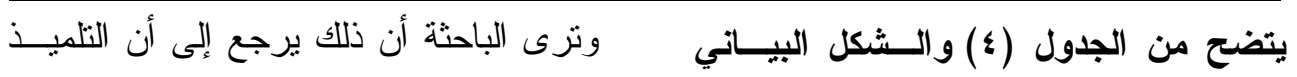

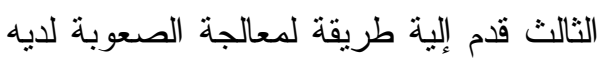

(السابق(r):

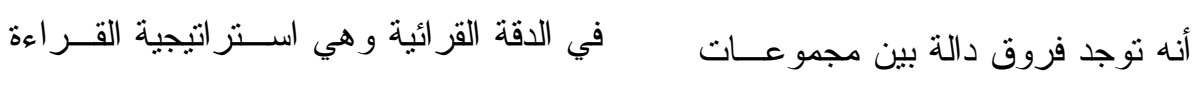

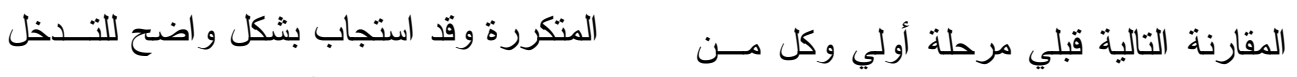

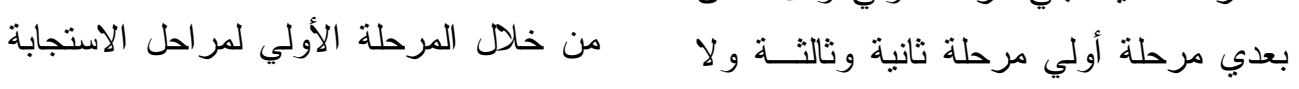

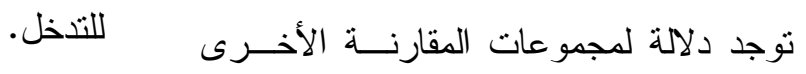

جدول (•)(الفروق بين الرتب في القياسات المتعددة وقيمة كا بللمعدل القرائي

\begin{tabular}{|c|c|c|c|}
\hline كاr & متوسط الرتب & المر احل & المتغير ات \\
\hline \multirow{4}{*}{ ^عدالة عند مستوي ا •, • } & $1, r \leq$ & القياس القبلي & \multirow{4}{*}{ اللتمبذ المعدل } \\
\hline & r,qY & القياس البعدي للمرحلة الأولي & \\
\hline & r,qr & القياس البعدي للمرحلة الثانبة & \\
\hline & $r, q r$ & القياس البعدي للمرحلة الثالثة & \\
\hline \multirow{4}{*}{ دالة عند مستوى دلالة ا .,. • } & $1, \leqslant V$ & القياس القبلي & \multirow{4}{*}{ ل اللتلميذ الثاني } \\
\hline & $r, \wedge \varepsilon$ & القياس البعدي للمرحلة الأولي & \\
\hline & $r, \wedge \varepsilon$ & القياس البعدي للمرحلة الثانية & \\
\hline & $r, \wedge \varepsilon$ & القياس البعدي للمرحلة الثالثة & \\
\hline \multirow{4}{*}{ 10 دالة عند مسنوي دلالة } & 1,17 & القياس القبلي & \multirow{4}{*}{ ل للتلميذ الثالث } \\
\hline & $r, 90$ & القباس البعدي للمرحلة الأولى & \\
\hline & $r, 90$ & القياس البعدي للمرحلة الثانية & \\
\hline & $r, 90$ & القياس البعدي للمرحلة الثالثة & \\
\hline \multirow{4}{*}{ - آخغير دال } & $r, r \varepsilon$ & 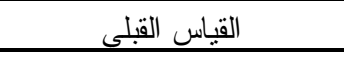 & \multirow{4}{*}{ 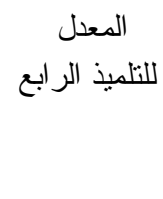 } \\
\hline & $r, \leq 0$ & القياس البعدي للمرحلة الأولي & \\
\hline & $r, 00$ & القباس البعدي للمرحلة الثانية & \\
\hline & $r, V T$ & القياس البعدي للمرحلة الثالثة & \\
\hline
\end{tabular}




\section{يتضح من الجدول السابق:}

بمر احله الثلاثة في بعد المعدل ويوضح ذلك

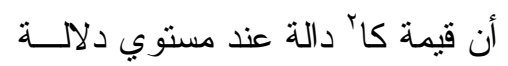

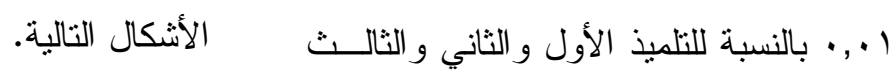

ولتحديد اتجاه الدلالة بين متوســطات

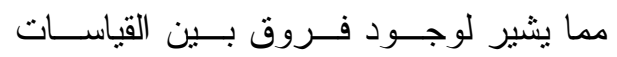

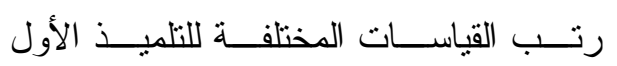

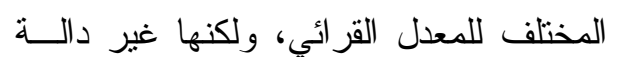

استخدمت الباحثة أسلوب بوتفيروني للمقارنة

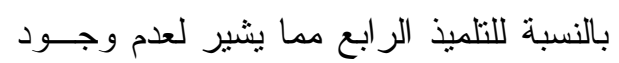

بين القياسات المختلفة في بعد المعدل القرائي

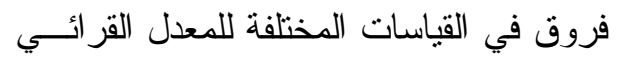

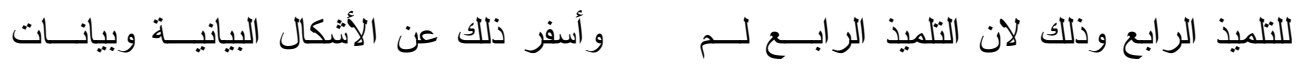
يجناز البرنامج القائم علي الاستجابة للتــدخل الجدول التالي:

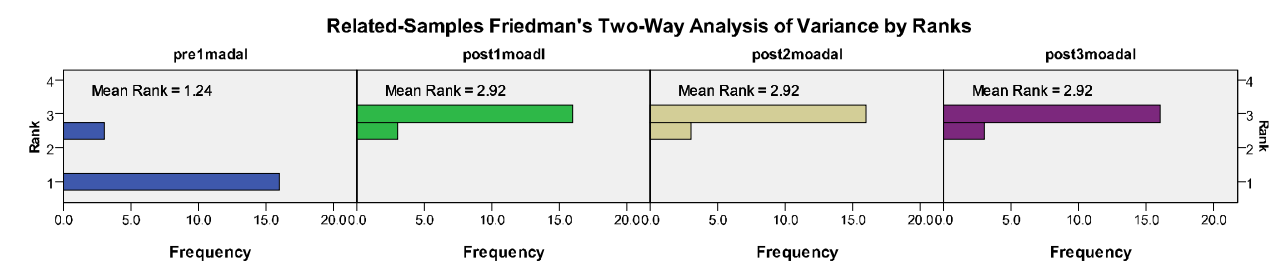

Pairwise Comparisons

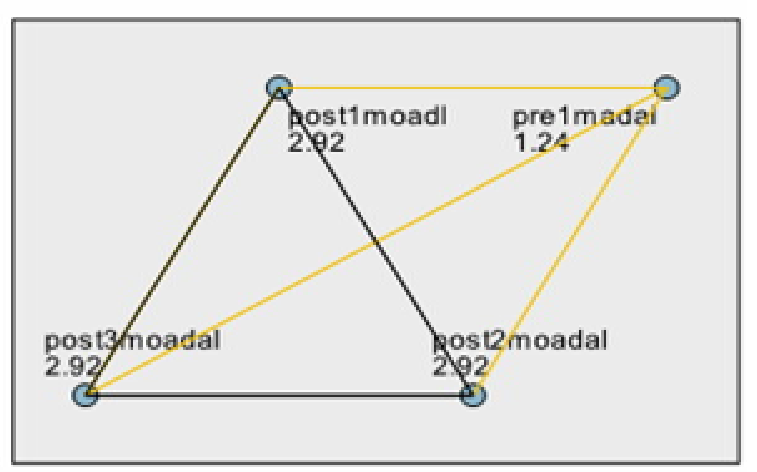

شكل (؛) رسم بياني يوضح أثار التذخل على متغير المعدل في القياسات المختلفة للتلميذ الأول 
جدول (•) المقارنة بين كل زوج من متوسطات القياسات المتكررة لبعد المعدل للتلميذ الأول

\begin{tabular}{|c|c|c|}
\hline الدلالة & الفروق بين المتوسطات & مجموعات المقارنة \\
\hline$\cdot, \cdot 1$ & $1,7 \wedge-$ & قبلى المرحلة الأولى/ بعدي المرحلة الأولى \\
\hline$\cdot, \cdot 1$ & $1, \wedge 7-$ & قبلي المرحلة الأولي/بعدي المرحلة الثانية \\
\hline$\cdot, \cdot 1$ & $1, \wedge 7-$ & قبلى المرحلة الأولى/ بعدي المرحلة الثالثة \\
\hline 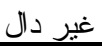 & صفر & بعدي مرحلة أولى/ بعدي مرحلة ثانية \\
\hline 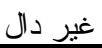 & صفر & بعدي مرحلة أولي/بعدي مرحلة ثالثة \\
\hline 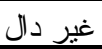 & صفر & بعدي مرحلة ثانية/بعدي مرحلة ثالثة \\
\hline
\end{tabular}

يتضح من الجدول (•) والشكل البياني السابق( ) ):

أنه نوجد فروق دالة بين مجموعـات من خلال المرحلة الأولي لمراحل الاستجابة

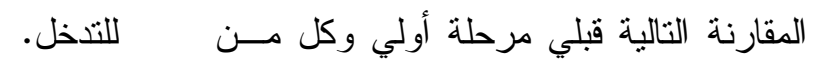

ولتحديد اتجاه الدلالة بين منوســطات

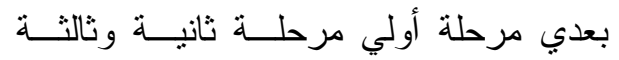

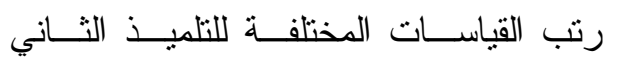

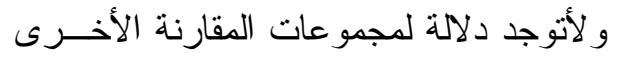
استخدمت الباحثة أسلوب بوتفيروني للمقارنة

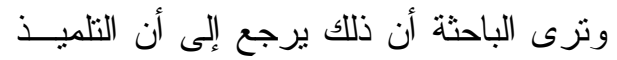
بين القياسات المختلفة في بعد المعدل القرائي

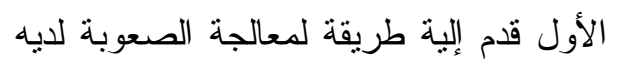
وأسفر ذلك عن الأثكال البيانيــة وبيانــات لئات

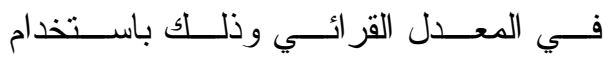
استر اتيجية القــر اعة بمسساعدة التـسجيلات الجدول التالي: الصوتية وقد استجاب بشكل و اضتح للتــدخل

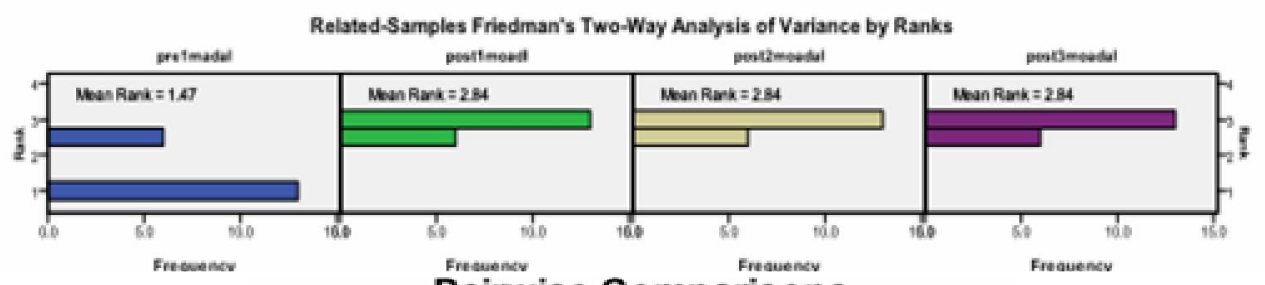

\section{Pairwise Comparisons}

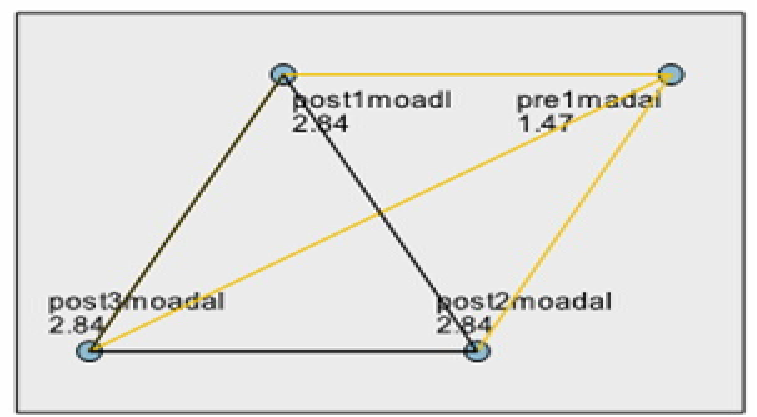

شكل (ه) رسم بياني يوضح أثار التخل على متغير المعدل في القياسات المختلفة للتلميذ الثاني 
جدول (†) المقارنة بين كل زوج من متوسطات القياسات المتكررة لبعد المعدل للتلميذ الثاني

\begin{tabular}{|c|c|c|}
\hline الدالة & الفزوق بين المتوسطات & مجموعات المقارنة \\
\hline$\cdot,, .1$ & 1, rq- & قبلى المرحلة الأؤلى/بعدي المرحلة الأولى \\
\hline$\cdot, ., 1$ & $1, \pi 4-$ & قبلى المرحلة الأولى/ بعدي المرحلة الثانية \\
\hline.,., 1 & $1, \Gamma 4-$ & قبلى المرحلة الأولى/ بعدي المرحلة الثالثة \\
\hline 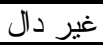 & صفز & بعدي مر حلة أولى/ بعدي مرحلة ثانية \\
\hline 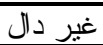 & صفر & بعدي مرحلة أولى/ بعدي مر حلة ثالثة \\
\hline 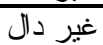 & صفر & بعدي مرحلة ثانية/بعدي مر حلة ثالثة \\
\hline
\end{tabular}

يتضح من الجدول (†) و الثكل البياني السابق:

أنه توجد فروق دالة بين مجموعـات من خلال المرحلة الأولي لمراحل الاستجابة

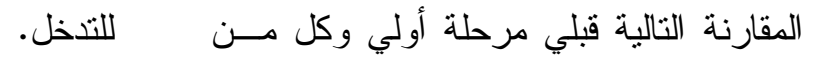

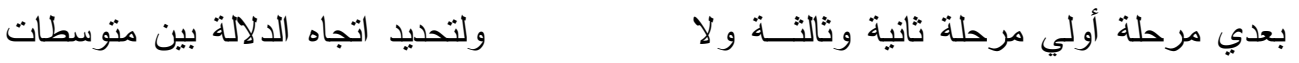

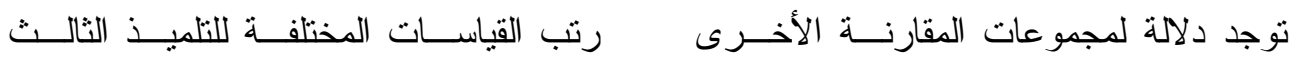

وتزى الباحثة أن ذلك يرجع إلي أن التلميـــ استخدمت الباحثة أسلوب بوتفيروني للمقارنة

الثاني قدم إلية طريقة لمعالجة الصعوبة لديه بين القياسات المختلفة في بعد المعدل القرائي

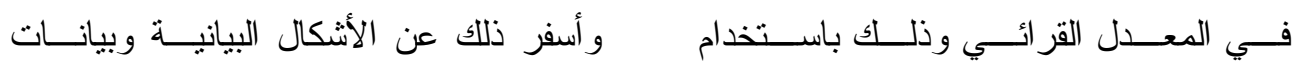

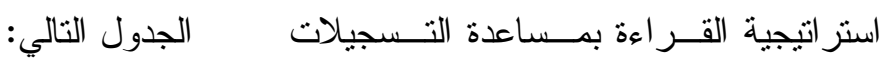

الصوتية وقد استجاب بشكل و اضتح للتــدخل

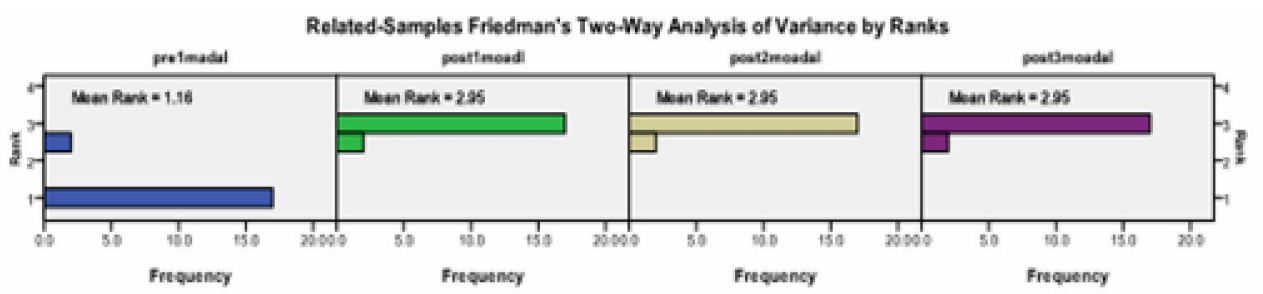

Pairwise Comparisons

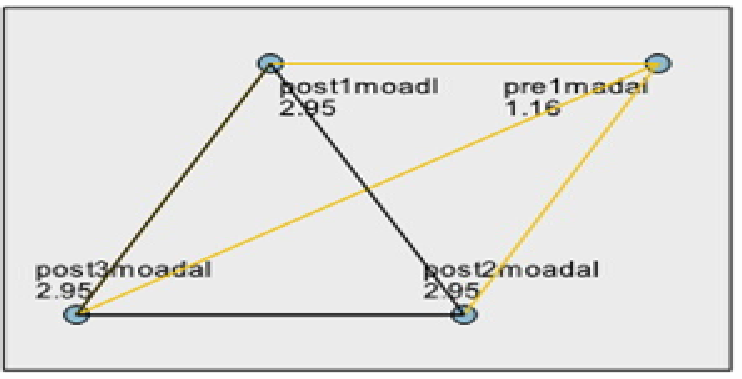

شكل (؟) رسم بياتي يوضح أثار التخل على متغير المعدل في القياسات المختلفة للتميذ الثالث 
جدول (V) المقارنة بين كل زوج من متوسطات القياسات المتكررة لبعد المعدل للتلميذ الثالث

\begin{tabular}{|c|c|c|}
\hline الالالة & الفروق بين المتوسطات & مجموعات المقارنة \\
\hline$\cdot, \cdot 1$ & $1, \vee \wedge-$ & قبلي المرحلة الأولي/ بعدي المرحلة الأولي \\
\hline$\cdot, \cdot 1$ & $1, \vee \vee \wedge-$ & قبلي المرحلة الأولي/بعدي المرحلة الثانية \\
\hline$\cdot, \cdot 1$ & $1, \vee \vee \wedge-$ & قبلي المرحلة الأولي/بعدي المرحلة الثالثة \\
\hline غير دال & صفر & بعدي مرحلة أولي/بعدي مرحلة ثانية \\
\hline 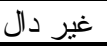 & صفر & بعدي مرحلة أولي/ بعدي مرحلة ثالثة \\
\hline غبر دال & صفر & بعدي مرحلة ثانبة/ بعدي مرحلة ثالثة \\
\hline
\end{tabular}

يتضح من الجدول (V) و الثنكل البياني السابق(†):

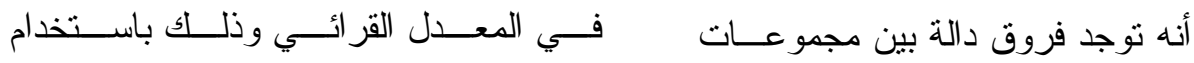

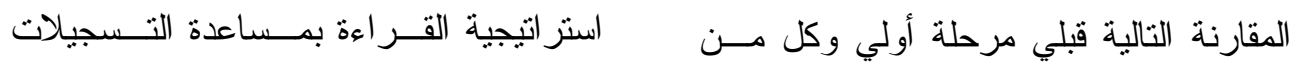

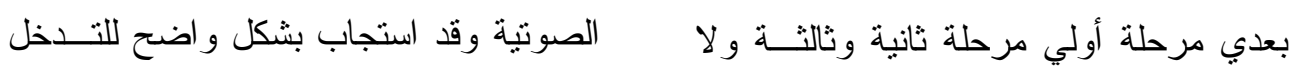

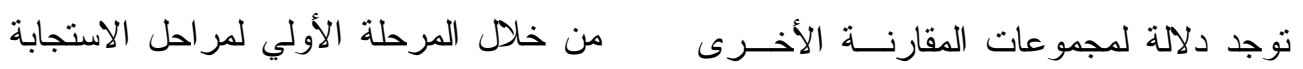

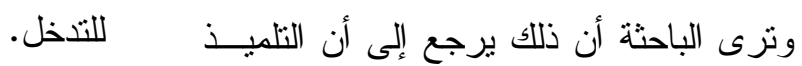

الثالث قدم إلية طريقة لمعالجة الصعوبة لدئ لديه

جدول (^)(الفروق بين الرتب في القياسات المتعددة وقيمة كا؟بتغيم القرائي

\begin{tabular}{|c|c|c|c|}
\hline SL & متوسط الرتب & المراحل & المتغيرات \\
\hline \multirow{4}{*}{ مستو دالة عند } & 1,11 & القباس القبلي & \multirow{4}{*}{ اللتلتميذ } \\
\hline & $r, 97$ & القياس البعدي للمرحلة الأولي & \\
\hline & $r, 97$ & القياس البعدي للمرحلة الثانبة & \\
\hline & $r, 97$ & القياس البعدي للمرحلة الثالثة & \\
\hline \multirow{4}{*}{ 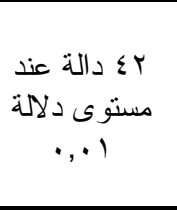 } & 1 & القياس القبلي & \multirow{4}{*}{ للالتلميذ الثناني } \\
\hline & $r$ & القياس البعدي للمرحلة الأولي & \\
\hline & $r$ & القياس البعدي للمرحلة الثانية & \\
\hline & $r$ & القياس البعدي للمرحلة الثالثة & \\
\hline \multirow{4}{*}{ 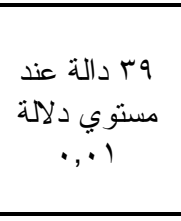 } & 1,11 & القياس القبلى & \multirow{4}{*}{ اللتلميذ التخالث } \\
\hline & $r, 97$ & القياس البعدي للمرحلة الأولى & \\
\hline & $r, 97$ & القياس البعدي للمرحلة الثانبة & \\
\hline & $r, 97$ & القياس البعدي للمرحلة الثالثة & \\
\hline \multirow{4}{*}{ 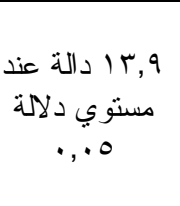 } & $r, \cdot \varepsilon$ & 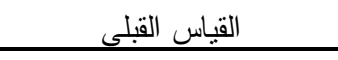 & \multirow{4}{*}{ التنغيم للتلميذ } \\
\hline & r,Tr & القياس البعدي للمرحلة الأولي & \\
\hline & $r, 7$ & القياس البعدي للمرحلة الثانية & \\
\hline & $r, . \varepsilon$ & القياس البعدي للمرحلة الثالثة & \\
\hline
\end{tabular}




\section{يتضح من الجدول السابق(^):}

ولتحديد اتجاه الدلالة بين متوســـات

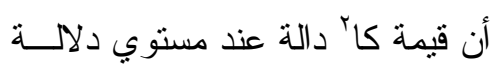

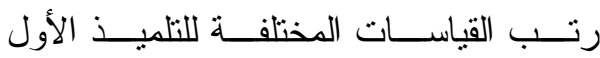

ا.,. • بالنسبة للتلميذ الأول و الثاني و الثالــث

استخدمت الباحثة أسلوب بوتفيروني للمقارنة

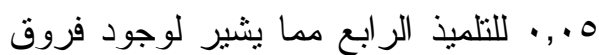

بين القياسات المختلفة في بعد التتغيم القرائي

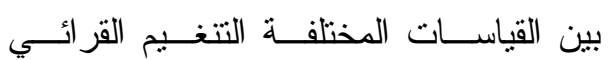

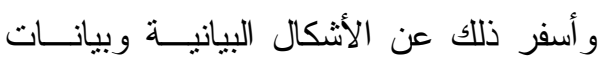

ويوضح ذلك الأشكال التالية.

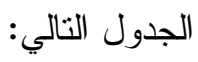

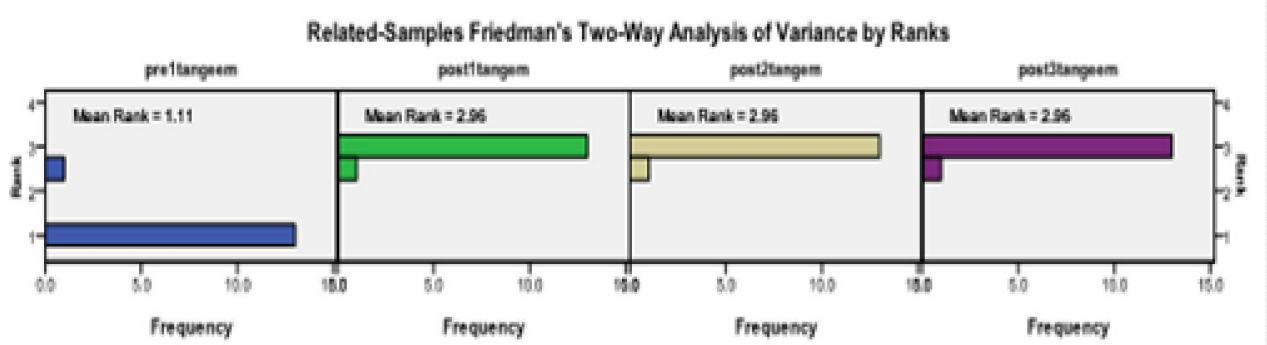

Pairwise Comparisons

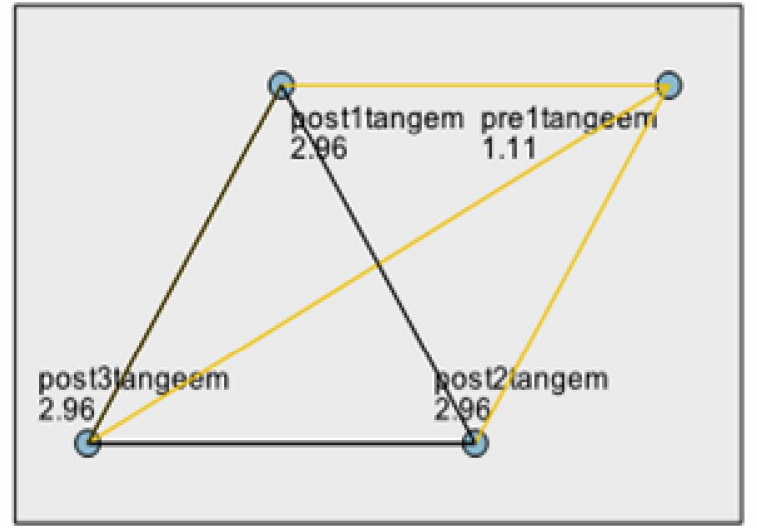

شكل (V) رسم بياني يوضح أثار التدخل على متغير التنغيم في القياسات المختلفة للتلميذ الأول 
جدول (9) المقارنة بين كل زوج من متوسطات القياسات المتكررة لبعد التنغيم للتلميذ الأول

\begin{tabular}{|c|c|c|}
\hline الدالة & الفزوق بين المتوسطات & مجموعات المقارنة \\
\hline.,., 1 & $1, \wedge 0-$ & قبلى المرحلة الأولى/ بعدي المرحلة الأولى \\
\hline$\cdot, \cdot, 1$ & $1,10-$ & قبلى المرحلة الأولى/ بعدي المرحلة الثانية \\
\hline$\cdot, \cdot 1$ & $1,10-$ & قبلى المرحلة الأولى/بعدي المرحلة الثالثة \\
\hline 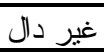 & صفر & بعدي مرحلة أولى/بعدي مرحلة ثانية \\
\hline 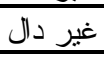 & صفر & بعدي مر حلة أولى/ بعدي مرحلة ثالثة \\
\hline غير دال & صفز & بعدي مر حلة ثانية/ بعدي مر حلة ثالثة \\
\hline
\end{tabular}

يتضح من الجدول (9) والسشكل البيـاني القراءة النموذجية وقد استجاب بشكل واضح

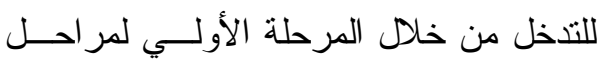
أنه توجد فروق دالة بين مجموعـات الاستجابة للتدخل.

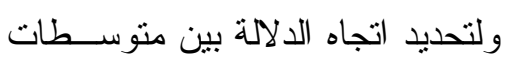

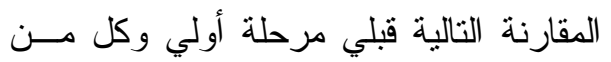

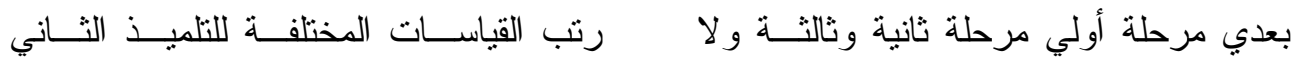

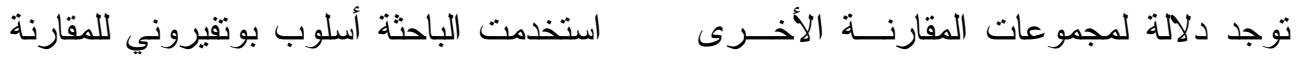
وتزى الباحثة أن ذلك يرجع إلى أن التلميـــ بين القياسات المختلفة في بعد التتغيم القرائي

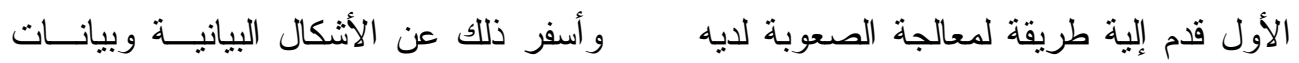
في التتغيم القر ائي وذلك باستخدام استر اتيجية الجدول التالي:

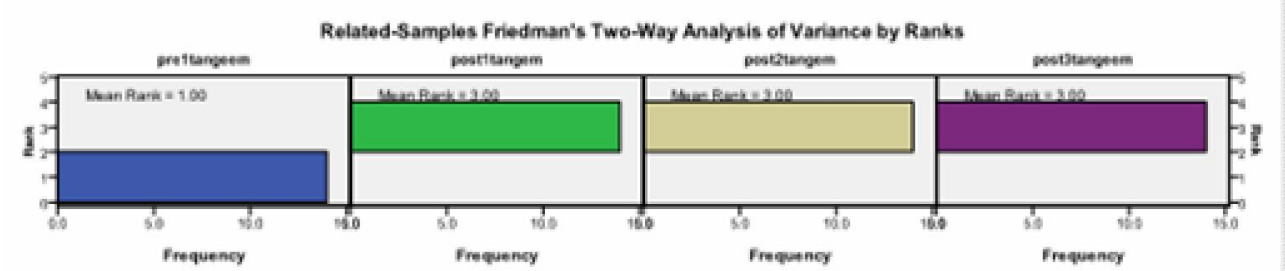

Pairwise Comparisons

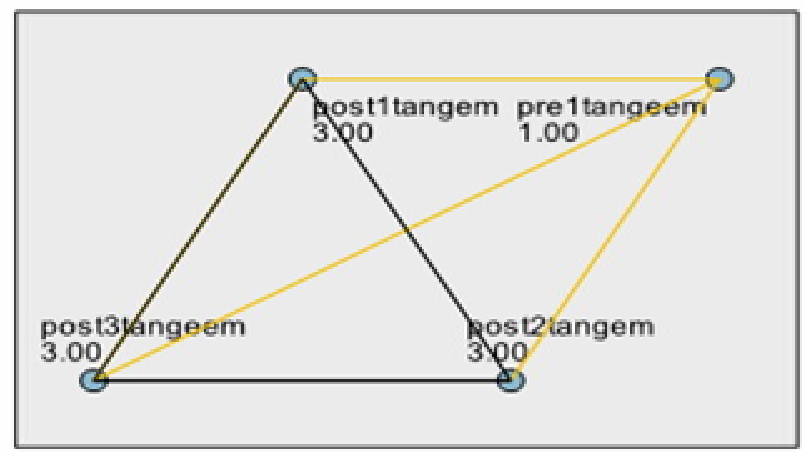

شكل (^) رسم بياني يوضح أثار التذخل على متغير التنغيم في القياسات المختلفة للتلميذ الثاني 
جدول ( • 1) المقارنة بين كل زوج من متوسطات القياسات المتكررة لبعد التتغيم للتلميذ الثاني

\begin{tabular}{|c|c|c|}
\hline الالالة & الفروق بين المتوسطات & مجموعات المقارنة \\
\hline$\cdot, \cdot 1$ & $r$ & قبلي المرحلة الأولي/ بعدي المرحلة الأولي \\
\hline$\cdot, \cdot 1$ & $r$ & قبلي المرحلة الأولي/بعدي المرحلة الثانبة \\
\hline$\cdot, \cdot 1$ & $r$ & قبلي المرحلة الأولي/بعدي المرحلة الثالثة \\
\hline غير دال & صفر & بعدي مرحلة أولي/ بعدي مرحلة ثانية \\
\hline 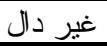 & صفر & بعدي مرحلة أولي/ بعدي مرحلة ثالثة \\
\hline غير دال & صفر & بعدي مرحلة ثانية/ بعدي مرحلة ثالثة \\
\hline
\end{tabular}

يتضح من الجدول (· 1) و الـشكل البيـاني القراءة النموذجية وقد استجاب بشكل و اضح

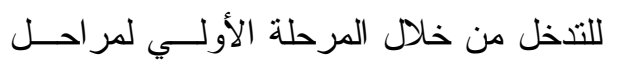

السابق(^):

أنه نوجد فروق دالة بين مجموعـات الاستجابة للتدخل.

ولتحديد اتجاه الدلالة بين متوســـات

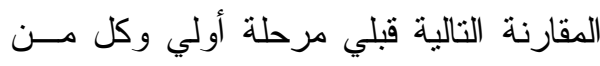

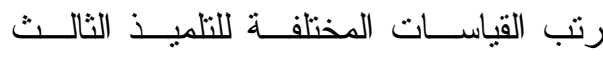

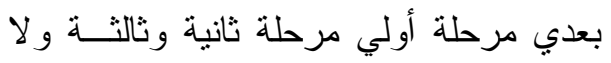
استخدمت الباحثة أسلوب بوتفيروني للمقارنة

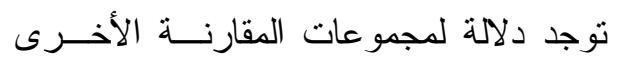
بين القياسات المختلفة في بعد التتغيم القرائي

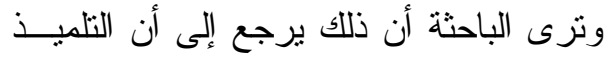

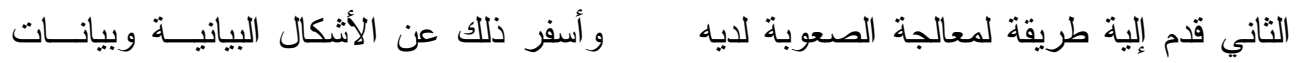
في التتغيم القر ائي وذلك باستخدام استر اتيجية الجدول التالي:

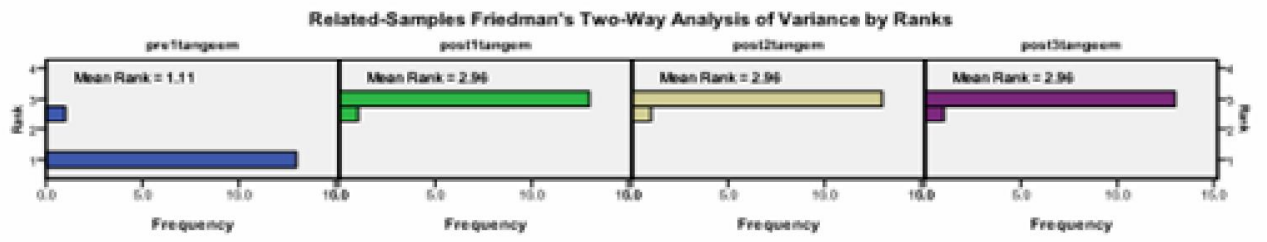

Pairwise Comparisons

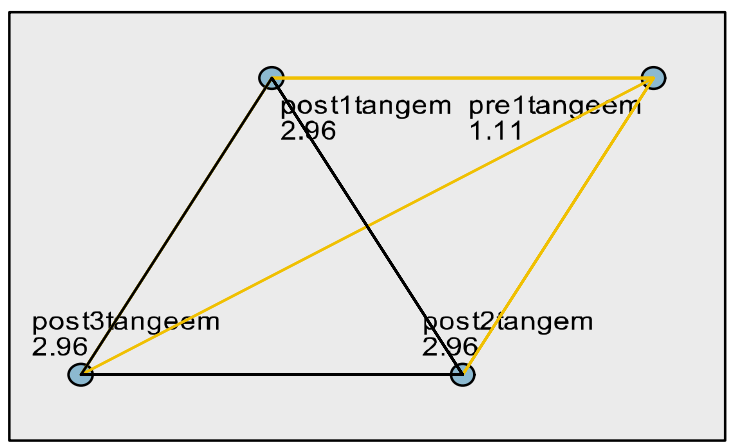

شكل (9) رسم بياني يوضح أثار التذخل على متغير التنغيم في القياسات المختلفة للتلميذ الثالث 
جدول (11) المقارنة بين كل زوج من متوسطات القياسات المتكررة لبعد التنغيم للتلميذ الثالث

\begin{tabular}{|c|c|c|}
\hline 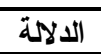 & الفروق بين المتوسطات & مجموعات المقارنة \\
\hline$\cdot, \cdot 1$ & $1,10-$ & قبلي المرحلة الأولي/ بعدي المرحلة الأولي \\
\hline$\cdot, \cdot 1$ & $1,10-$ & قبلي المرحلة الأولى/ بعدب المرحلة الثانية \\
\hline$\cdot, \cdot 1$ & $1,10-$ & قبلي المرحلة الأولى/ بعدي المرحلة الثالثة \\
\hline غير دال & صفر & بعدي مرحلة أولى/ بعدي مرحلة ثانبة \\
\hline غبر دال & صفر & بعدي مرحلة أولى/ بعدي مرحلة ثالثة \\
\hline غير دال & صفر & بعدى مرحلة ثانية/ بعدي مرحلة ثالثة \\
\hline
\end{tabular}

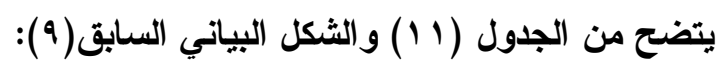

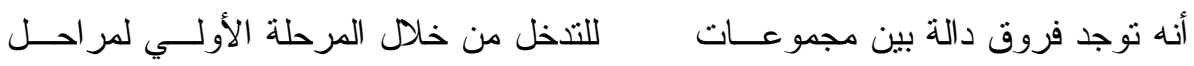

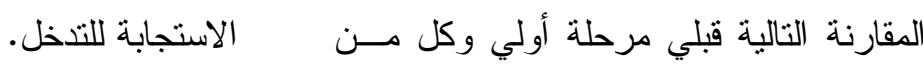

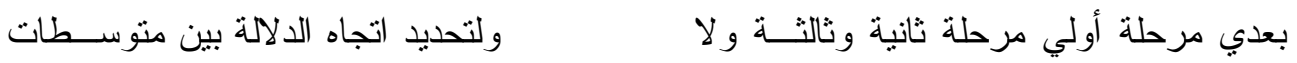

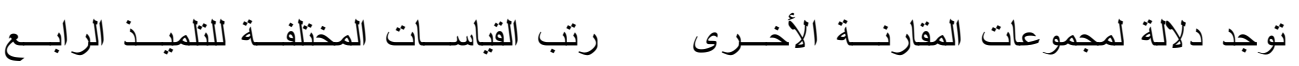

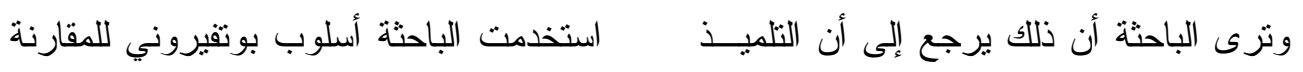

الثالث قدم إلية طريقة لمعالجة الصعوبة لديه إنيه بين القياسات المختلفة في بعد التتغيم القرائي

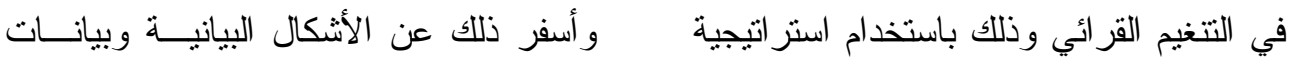

القر اءة النموذجية وقد استجاب بشكل واضح الجدول التالي:

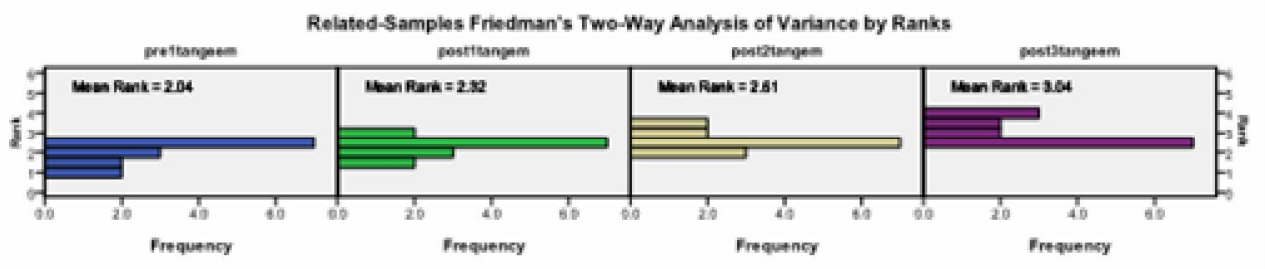

Pairwise Comparisons

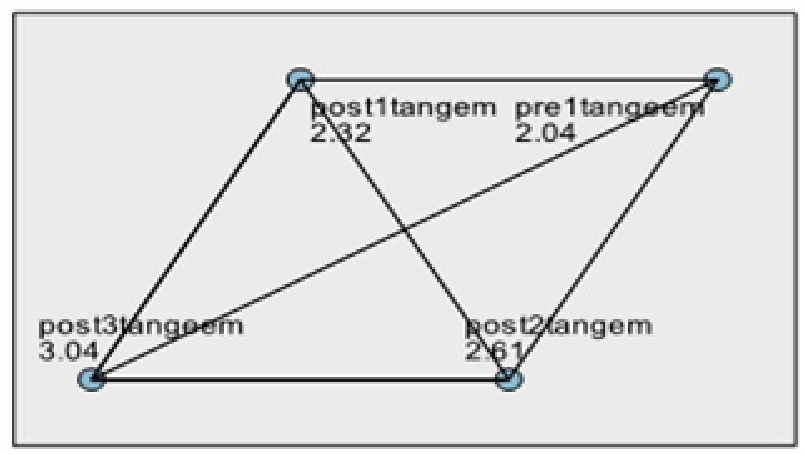

شكل (• 1) رسم بياني يوضح أثار التذخل على متغير التنغيم في القياسات المختلفة للتلميذ الرابع 
جدول (Y I ) المقارنة بين كل زوج من متوسطات القياسات المتكررة لبعد التنغيم للتلميذ الرابع

\begin{tabular}{|c|c|c|}
\hline الدلالة & الفروق بين المتوسطات & مجموعات المقارنة \\
\hline 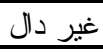 & , YАฯ & قبلي المرحلة الأولي/بعدي المرحلة الأولي \\
\hline غير دال & $\cdot, 0 \mathrm{~V}-$ & قبلي المرحلة الأولي/بعدي المرحلة الثانية \\
\hline$\cdot, .0$ & $1-$ & قبلى المرحلة الأولى/بعدي المرحلة الثالثة \\
\hline غير دال &., YА५- & بعدب مرحلة أولى/ بعدي مرحلة ثانية \\
\hline غير دال & صفر & بعدي مرحلة أولى/ بعدي مرحلة ثالثة \\
\hline 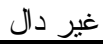 & صفز & بعدي مرحلة ثانية/ بعدي مرحلة ثالثة \\
\hline
\end{tabular}

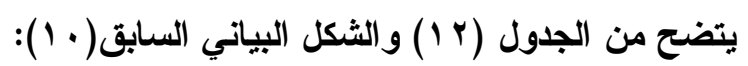

فتحي مصطفى الزيات (1991) (1): صــوبات التعلم الأسس النظرية و التشخيــصية

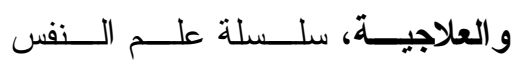

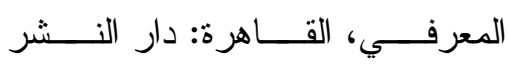
للجامعات.

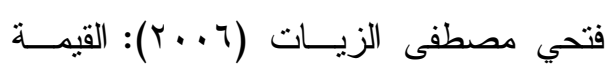

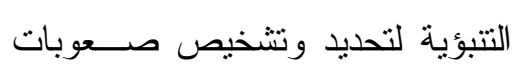

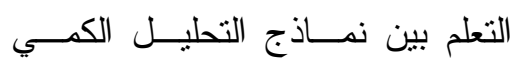

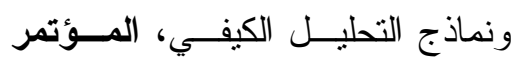
الدولي لصعوبات التعلم، الريــاض، لئل

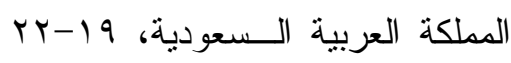

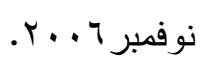

فتحي مصطفى الزيات (10 • ب): صــوبات

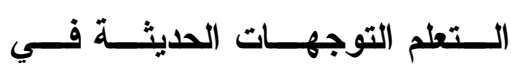
التشخيص و العلاج، القاهرة: مكتبــــة

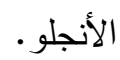

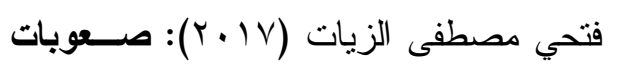
التعلم الأسس النظرية والتشخيـصية و العلاجية، تحت الطبع.
أنه توجد فروق دالة بــين مجموعــة

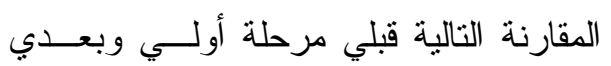
مرحلة ثالثة وذلك لأن النلميذ قد تحسن فـي لئي نهاية القياس البعدي للمرحلة الثالثة إلا أنه لم

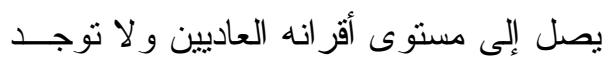

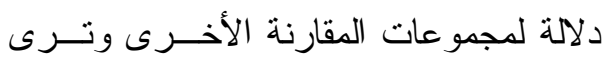

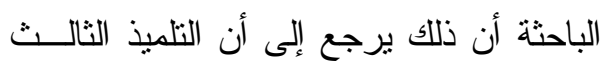

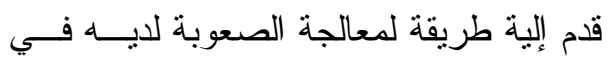
التتغيم القر ائي وذلك باســـتخدام اســـتر اتيجية

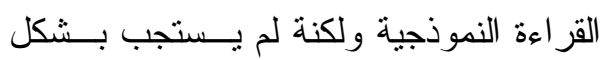

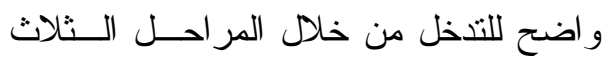
لنموذج الاستجابة للتدخل. المراجع أحمد عبد اللطيف أبو أسعد (10 • ب): حقيبة البر امج العلاجية في صعوبات التعلم، عمان، المملكة الأردنيـــة الهاثــــية:

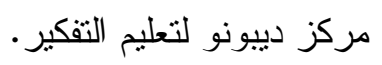
عماد أحمد حسسن علـى (ع ا • ب): تقنـين اختبار المصفوفات المتتابعة لرافن، القاهرة: مكتبة الأنجلو المصرية. 
practice (pp. 369-426). Mahwah: Lawrence Erlbaum.

Kuhn, M. IL, \& Stahl, S.A. (2002).

Fluency: a review of development and remedial practices. Journal of Educational Psychology, 93(I), 3-21.

Marple, G. M. (2012). Specific Learning Disabilities

Guidance for West Virginia School and Districts. Virginia Department of Education, Office of Special Programs. Retrieved from www.doe.virginia.Gov.

Morgan, Sh. R.A., Ramp, E. M., Anderson, Lt., \& Martin, a. M, (2007). Effects of repeated readings, error correction, and performance feedback on the fluency and comprehension of middle school.

Rasinski, T.V. (2003). The fluent reader: oral reading strategies for building word recognition, fluency, and comprehension. New York: Scholastic. Reconceptualizing identification of learning disabilities.

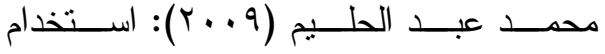

$$
\begin{aligned}
& \text { استر اتيجية القراءة المتكررة لزيـادة } \\
& \text { الطلاقة و أثزه في التعـرف و الفهـ }
\end{aligned}
$$

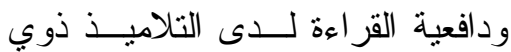

$$
\begin{aligned}
& \text { صعوبات القـــراءة بالــــف الثنالـــث } \\
& \text { الابتدائي. المجلـــة العلميـــة لكليـــة }
\end{aligned}
$$

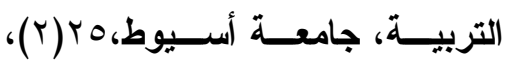

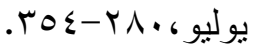

Brezntiz, Zvia (2006): Fluency in reading: Synchronization of processes. Mahwah- New Jersey: Lawrence Erlbaum Associates, Inc.

Disabilities Research \& Practice, 13, 204-219.

Fraser, C. (2004). Reading Fluency in Second Language. The Canadian Modern Language Review, 61(1), 135-160.

Fuchs, L., \& Fuchs, D. (1998). Treatment validity: A unifying concept for

Kavale, K. A. (2002). Discrepancy Models in the identification of learning disability. In R. Bradley, L. D. Hallahan (Eds.) Identification of learning disability: Research to 